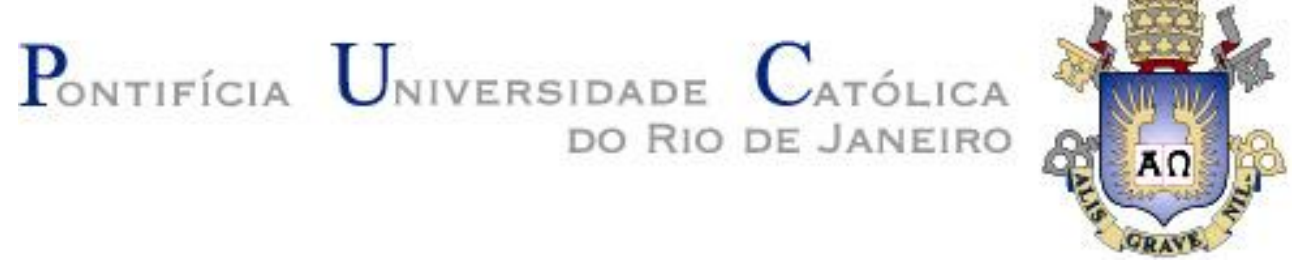

Denise Saboia Medeiros Vidal

A compreensão da accountability nas rotinas de controles internos

Dissertação de Mestrado

Dissertação apresentada ao Programa de Pósgraduação em Administração de Empresas da PUCRio como requisito parcial para obtenção do grau de Mestre em Administração de Empresas

Orientadora: Profa. Sandra Regina Rocha Pinto

Rio de Janeiro

Abril de 2018 


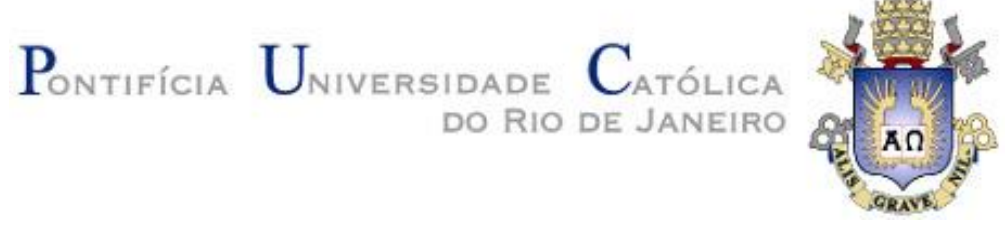

Denise Saboia Medeiros Vidal

\title{
A compreensão da accountability nas rotinas de controles internos
}

Dissertação apresentada como requisito parcial para obtenção do grau de Mestre pelo Programa de PósGraduação em Administração de Empresas da PUCRio. Aprovada pela Comissão Examinadora abaixo assinada.

\author{
Prof. Sandra Regina Rocha-Pinto \\ Orientadora \\ Departamento de Administração - PUC-Rio \\ Prof. Flávia de Souza Costa Neves Cavazotte \\ Departamento de Administração - PUC-Rio
}

Prof. Valter de Assis Moreno Jr

Faculdades IBMEC

Prof. Augusto Cesar Pinheiro da Silva Vice-Decano de Pós-Graduação do CCS - PUC-Rio

Rio de Janeiro, 27 de abril de 2018 
Todos os direitos reservados. É proibida a reprodução total ou parcial do trabalho sem autorização da universidade, da autora e da orientadora.

\section{Denise Saboia Medeiros Vidal}

Bacharel em Administração de Empresas, graduou-se em 2011 pela PUC-RJ. Pós graduada em 2014 em gestão de projetos pelo IBMEC-RJ, possui 8 anos de experiência nas áreas de controles internos e compliance com ênfase no mercado segurador.

Ficha Catalográfica

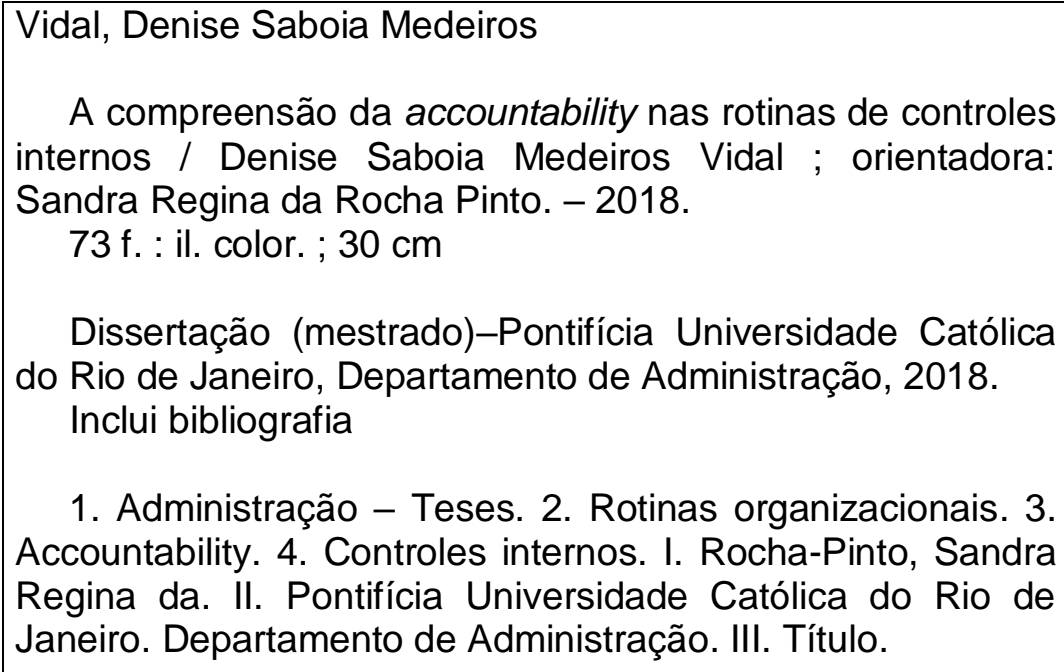

Dissertação (mestrado)-Pontifícia Universidade Católica do Rio de Janeiro, Departamento de Administração, 2018. Inclui bibliografia

1. Administração - Teses. 2. Rotinas organizacionais. 3. Accountability. 4. Controles internos. I. Rocha-Pinto, Sandra Regina da. II. Pontifícia Universidade Católica do Rio de Janeiro. Departamento de Administração. III. Título. 
Aos meus pais, pela força, amor e anos de dedicação. Para o meu marido, que devota a mim uma paciência memorável.

Para os meus irmãos, pelo carinho devotado. Para os meus amigos, que compreenderam minha caminhada. 


\section{Agradecimentos}

A Deus, por me acompanhar sempre nos meus sonhos.

À minha orientadora inspiradora, Sandra. Pela paciência, pelo dom de ser uma professora de alma, por compreender a vida de um aluno, por todos os ensinamentos. Você sempre terá minha admiração. Muito obrigada!

À minha mãe, pelos dias de trabalho vendendo livros para que eu tivesse os meus. Mãe, nunca me esquecerei. Te amo!

Ao meu pai, a quem devoto minha saudade mais profunda. Agradeço pelos calos que fez em tuas mãos, para que os meus calos fossem em minha mente. Tudo que eu fizer em minha vida sempre será dedicado a você.

Ao meu marido, que cultiva uma paciência e amor verdadeiros. Era você quem estava comigo nesse caminho diariamente e te agradeço por tudo.

À toda a minha família, pela torcida, carinho e atenção diária. Em especial a minha irmã Andrea, que me ligava sempre perguntando como estava a dissertação e me dava força para terminar.

À minha amiga Kelly, pela fortaleza, compreensão e companheirismo que dividimos. Você tem um pedacinho dessa dissertação.

Aos docentes do curso, vocês são sensacionais. Tenho orgulho de ter compartilhado essa caminhada com vocês.

Aos meus amigos, que tiveram paciência quando eu disse que não poderia dar atenção, pois tinha um compromisso com o mestrado. É bom saber que vocês me esperaram.

Aos meus companheiros do mestrado, pela oportunidade em desenvolver a convivência com pessoas tão diferentes.

Às minhas amigas e companheiras de organizações, em especial, Ana Paula e Alane, vocês me mantiveram forte e me deram o apoio que, por vezes, precisei.

A todos os funcionários do IAG, vocês estiveram presentes e sempre dispostos a nos atender.

À Pontifícia Universidade Católica do Rio de Janeiro - PUC-RJ, aos secretários, bibliotecários, coordenadores, diretores, professores e demais funcionários. Não escolheria outra universidade, vocês me fazem ter orgulho de ser filha da PUC. 


\section{Resumo}

Vidal, Denise Saboia Medeiros; Rocha-Pinto, Sandra Regina da. A compreensão da accountability nas rotinas de Controles Internos. Rio de Janeiro, 2018. 73p. Dissertação de Mestrado - Departamento de Administração, Pontifícia Universidade Católica do Rio de Janeiro.

O cenário do Brasil hoje está permeado por escândalos de corrupção, lavagem de dinheiro, formação de quadrilha, dentre outros crimes que envolvem grandes empresas e o poder público. Nesse sentindo, as rotinas de controle interno, bem como os procedimentos que envolvem um sistema de Controles Internos, surgem como instrumentos fundamentais para lidar com esse cenário. Utilizando o conceito de accountability fornecido por Pinho e Sacramento (2008) e sob o olhar das rotinas organizacionais e as peculiaridades do controle interno, o presente estudo pretendeu investigar a forma como os profissionais entendem a accountability nas rotinas de controles internos. A partir de uma abordagem fenomenográfica foram entrevistados 20 profissionais nomeados de agentes de Controles Internos em uma seguradora, localizada na cidade do Rio de Janeiro, no período de 09/08/2017 a 09/10/2017. As análises retornaram três concepções: a primeira relaciona-se ao respeito aos artefatos, a segunda envolve qualificar as rotinas e a terceira diz respeito a proteger a organização. Ademais, as dimensões explicativas das concepções foram identificadas de acordo com seguintes categorias: deferência à transparência; intensidade da interação dos aspectos; o senso de responsabilidade e o respeito ao controle. Os achados sugerem que há uma construção de concepções que evolui do instrumental à percepção de valor. Além disso, as evidências indicam que os profissionais possuem uma percepção significativa de responsabilidade nas rotinas de controles internos e, por fim, traz à luz a relação entre a melhoria dos processos e a intensidade da interação entre os aspectos ostensivo e performativo da rotina organizacional.

\section{Palavras-chave}

Rotinas organizacionais; accountability; controles internos. 


\section{Abstract}

Vidal, Denise Saboia Medeiros; Rocha-Pinto, Sandra Regina da (Advisor). Understanding accountability in internal control routines. Rio de Janeiro, 2018. 73p. Dissertação de Mestrado - Departamento de Administração, Pontifícia Universidade Católica do Rio de Janeiro.

Brazil's today scenario is full of corruption scandals, money laundering, racketeering, among other crimes involving large corporations and public power. Bearing this in mind, the internal control routines, as well as the procedures that involve an Internal Control system, appear as fundamental tools to deal with this scenario. Using Pinho \& Sacramento's concept of accountability (2008) and under the watch of organizational routines and peculiarities of internal control, the present study was aimed to investigate how professionals understand accountability in internal control routines. From a phenomenological approach 20 professionals were interviewed, all of them working in Internal Control department of an insurance company located in Rio de Janeiro City, from 09/08/2017 to 09/10/2017. The analyzes returned three concepts: the first is related to the respect with the artifacts, the second involves qualifying routines, and the third concerns to the organization protection. In addition, the explanatory dimensions of the concepts were identified according to the following categories: deference to transparency; intensity of interaction aspects; the sense of responsibility and respect for control. The findings suggest that there is a construction of concepts that evolves from instrumental to perception of value. In addition, the evidence indicates that professionals have a significant perception of responsibility in the routines of internal controls. And finally, brings to light the relationship between process improvement and the interaction intensity between the ostensible and performative aspects of organizational routines.

\section{Keywords}

Organizational routines; accountability; internal control. 


\section{Sumário}

1 O problema 12

1.1. Introdução 12

1.2. Objetivo final 13

1.3. Objetivos Intermediários 13

1.4. Delimitação do estudo 14

1.5. Relevância do estudo 15

2 Referencial teórico 16

2.1. Rotinas Organizacionais 16

2.1.1. Aspecto Ostensivo 17

2.1.2. Aspecto Performativo 18

2.1.3. Artefatos 18

2.1.4. As inter-relações entre aspectos ostensivos, performativos e artefatos 19

2.2. Controles Internos $\quad 21$

2.3. O Conceito de Accountability 25

3 Procedimentos Metodológicos $\quad 28$

3.1. Aspectos epistemológicos e ontológicos 28

3.2. Tipo de Pesquisa $\quad 29$

3.3. Abordagem da Pesquisa Fenomenográfica 30

3.4. A fenomenografia e suas relações 31

3.5. Justificativa da abordagem da pesquisa 33

3.6. Coleta de Dados 33

3.7. Seleção dos sujeitos $\quad 34$

3.8. Formulação do Roteiro de Entrevistas 36

3.9. Condução das entrevistas 37

3.10. Tratamento e Análises dos Dados que Emergem do Campo 38

3.10.1. Tratamento dos Dados 38

3.10.2. Análise dos Dados 39

3.11. Limitações da Abordagem de Pesquisa 41

4 Resultados encontrados $\quad 42$

4.1. A empresa 43

4.2. As categorias descritivas e as dimensões explicativas 43

$\begin{array}{ll}\text { 4.2.1. Respeitar os artefatos } & 47\end{array}$

4.2.2. Qualificar as rotinas $\quad 50$

4.2.3. Proteger a organização $\quad 55$

4.3. O Espaço de Resultados $\quad 60$

5 Considerações finais 61

5.1. Sugestões e recomendações para novas pesquisas 65

6 Referências Bibliográficas $\quad 67$

Apêndice I Roteiro Semi-Estruturado $\quad 71$

Apêndice II Lista de Termos Específicos $\quad 71$ 


\section{Lista de figuras}

Figura 1: Rotinas organizacionais como sistemas generativos 20 Figura 2: Elaborado pelo Committee of Sponsoring Organizations
of the Treadway Commission Figura 3: Adaptado de Koppell (2005). 26

Figura 4: As relações na fenomenografia. 31

Figura 5: Hierarquia das categorias descritivas. 44 


\section{Lista de quadros}

Quadro 1: Características dos sujeitos que participaram da pesquisa 35 
Não te deixes destruir...

Ajuntando novas pedras e construindo novos poemas.

Recria tua vida, sempre, sempre. Remove pedras e planta roseiras e faz doces.

Recomeça.

Faz de tua vida mesquinha um poema.

E viverás no coração dos jovens e na memória das gerações que hão de vir. Esta fonte é para uso de todos os sedentos.

Toma a tua parte.

Vem a estas páginas e não entraves seu uso aos que têm sede.

Cora Coralina 


\section{O problema}

O propósito deste capítulo é apresentar o problema de pesquisa e os desconfortos e interesses que favoreceram a observação do fenômeno. Sendo assim, o capítulo se divide numa introdução a respeito do problema, culminando na questão central da pesquisa. Posteriormente, o objetivo final, bem como os objetivos intermediários a respeito da investigação são apresentados; as delimitações; e a exposição dos argumentos que discutem a relevância do presente estudo para sociedade, o ambiente organizacional e as comunidades acadêmicas.

\section{1. Introdução}

Segundo a Associação dos Investigadores Certificados de Fraude Americana, a ACFE (2016), cerca US\$ 6,2 milhões do faturamento das empresas analisas foram perdidos em virtude de fraudes, e estimam que esse valor aumente em centenas ou até milhares de dólares numa escala global. Em uma matéria do jornal Estadão (2014), especialistas em governança corporativa apresentam preocupações quanto aos poucos investimentos em estruturas e procedimentos de governança nas empresas privadas do Brasil. A matéria ainda apresenta dados de uma pesquisa realizada pela consultoria Deloitte que revela que, de 124 companhias pesquisadas, 55\% já tiveram casos de corrupção e que, das empresas pesquisadas, os investimentos anuais em compliance, por exemplo, não extrapolam $R \$ 1$ milhão por ano, valor considerado pequeno aos analistas da Deloitte.

Os dados apresentados servem para corroborar as ponderações de Campos (1990) que, depois de ter contato com a palavra accountability em uma experiência acadêmica nos Estados Unidos, incomodou-se tanto com a ausência da tradução, bem como do conceito repleto de significados. Para a autora, aspectos políticos, que envolvem tanto a falta de transparência do governo quanto a desorganização da sociedade civil e cidadãos que não velam, nem são conscientes de seus direitos, culminam em reduzida consciência acerca de accountability. 
Algumas empresas reguladas, como financeiras e seguradoras, já possuem estruturas e procedimentos formais de controles internos por obrigação regulatória. A exigência para as seguradoras, por exemplo, vem desde o ano de 2004. A Superintendência de Seguros Privados (SUSEP) estabeleceu na Circular 249 a implantação e implementação de um sistema de controles internos para as seguradoras e outras entidades. Nessa lógica, pareceu oportuno utilizar os estudos das rotinas organizacionais (PARMIGIANI e HOWARD-GRENVILLE, 2011; PENTLAND e FELDMAN, 2005) como campo e suporte a análise e avaliação do fenômeno a ser estudado, dado que os procedimentos de governança são permeados por processos fortemente formalizados, a exemplo, as rotinas de conformidade (CHERMAN e ROCHAPINTO, 2016), além das relações entre os outros componentes da rotina organizacional, constituindo a estrutura interna da rotina (PENTLAND e FELDMAN, 2005).

Desta forma, partindo de um paradigma interpretativista, utilizando uma abordagem metodológica fenomenográfica (ARKELIND, 2005), este estudo pretende responder à seguinte pergunta de pesquisa: Como os profissionais compreendem a incorporação da accountability nas rotinas de controles internos?

\section{2. \\ Objetivo final}

Partindo da dificuldade em traduzir ou mesmo verificar a presença do conceito de accountability no Brasil (CAMPOS, 1990; PINHO e SACRAMENTO, 2008), dos múltiplos significados atribuídos a palavra (KOPPELL, 2005), mesmo em sua língua de origem, e do cenário político e econômico que exige o estabelecimento de uma estrutura de controles internos, a exemplo da Superintendência de Seguros Privados, SUSEP (2004), o objetivo final deste trabalho é compreender como os profissionais entendem a accountability no contexto das rotinas de controles internos.

\section{3. \\ Objetivos intermediários}

A fim de responder à questão central de pesquisa e auxiliar o presente estudo alcançar o objetivo final, os seguintes objetivos intermediários foram estipulados: 
- Revisar a evolução teórica e as discussões acadêmicas contemporâneas acerca das rotinas organizacionais;

- Identificar os principais conceitos de accountability e os debates relacionados ao tema;

- Identificar as diferentes maneiras, a partir de uma pesquisa qualitativa, que os indivíduos percebem ou vivenciam a accountability no contexto das rotinas de controles internos;

- Descrever os relacionamentos lógicos entre as principais concepções dos envolvidos frente ao fenômeno estudado.

\section{4.}

\section{Delimitação do estudo}

Partindo de uma abordagem interpretativista (VERGARA e CALDAS, 2005) sob uma ontologia não dualista (AKERLIND, 2005), a pretensão deste estudo consiste em observar o fenômeno accountability a partir das perspectivas do grupo envolvido no campo das rotinas organizacionais, mais especificamente, nas rotinas de controles internos. A pesquisa buscou colher as principais concepções, suas semelhanças e diferenças, a partir do método fenomenográfico (AKERLIND, 2005; MARTON, 1981). Apesar de utilizar como norteador o conceito de Pinho e Sacramento (2008) a respeito da accountability e as preocupações outrora apresentadas por Campos (1990), este estudo não pretende aprofundar as questões relacionadas à administração pública discutidas pelos autores, mas observar o conjunto de significados que emerge da experimentação do fenômeno por parte dos indivíduos (MARTON e BOOTH, 1997). 


\section{5.}

\section{Relevância do estudo}

Em um período não muito distante, Campos (1990) apresentou sua preocupação quanto a ausência não apenas do termo accountability, mas do significado, do conceito e da importância aos brasileiros. Apesar de ter passado quase trinta anos, desde a exposição de suas preocupações frente à accountability, a cidadania brasileira e a administração pública, a reflexão de Campos (1990, apud CAMARGO, 1987) frente as palavras de Camargo não nos parece muito distante, visto que a autora expõe as considerações do autor sobre a existência de um colapso de credibilidade; um país que não pode confiar em suas instituições e uma crise econômica que aparenta ser o outro lado de uma moeda da crise política. Pinho e Sacramento (2008) conseguiram vislumbrar sinais de mudanças, mas ainda enxergaram dificuldades para mudanças profundas e estruturais dado que o Brasil carrega séculos de uma cultura conservadora. Os autores concluem que apesar de estar no caminho, ainda havia muito a percorrer para se construir uma cultura de accountability.

Dado que tantos conceitos do exterior são incorporados como "melhores práticas de governança", padrões internacionais são exigidos por mercados intercontinentais, valores que envolvem transparência, responsabilidade e compromisso, muitas dessas questões explícitas nas rotinas organizacionais (PARMIGIANI e HOWARD-GRENVILLE, 2011; PENTLAND e FELDMAN, 2005) o presente estudo busca contribuir com uma revisão frente às preocupações de Campos (1990) e Pinho e Sacramento (2008). Apesar deste estudo não poder generalizar a todos os brasileiros, a ideia é obter a percepção de accountability de um grupo já envolvido nos padrões atuais de mercado, em um ambiente organizacional privado, que segue regulamentações formais externas e internas e talvez, ao cabo da pesquisa, poder fornecer um vislumbre sobre como esses profissionais vivenciam ou percebem a accountability no contexto das rotinas de controles internos. 


\section{2 Referencial teórico}

Neste capítulo são apresentados fundamentos teóricos que suportam o problema de pesquisa. Como constructo principal esta seção abordará as rotinas organizacionais, os aspectos ostensivos e performativos, bem como sua relação e o papel dos artefatos nas rotinas. $\mathrm{Na}$ segunda seção, o leitor encontrará conceitos e definições relacionados ao tema de controles internos, no qual conhecerá os desdobramentos do conceito. Nessa mesma linha, a terceira seção tratará de expor o conceito de accountability, fenômeno observado nesta pesquisa, culminando no significado utilizado por Pinho e Sacramento (2008) utilizado como apoio na pesquisa deste estudo. Essas discussões e desenvolvimentos teóricos são necessários para análise dos achados de pesquisa.

\section{1. \\ Rotinas organizacionais}

As rotinas comumente fazem parte do dia-a-dia de uma organização seja ela, pública ou privada. Diversos estudos focaram em investigar os aspectos que envolvem a rotina organizacional, suas características e definições. Nelson e Winter (1982) consideram as rotinas como fortes componentes das organizações. Feldman e Pentland (2003) refletem que vários autores utilizam as metáforas para conceituar ou explicar as rotinas e seu funcionamento, mas que, em sua maioria tendem a considerar as rotinas organizacionais como "fixas e imutáveis" (WEISS e ILGEN, 1985; BAUM e SINGH, 1994) contrapondo a ideia de que possam ser "flexíveis e mutáveis" (PENTLAND e RUETER, 1994; FELDMAN, 2000).

Considerando os estudos organizacionais e as distintas explicações frente às características e aos comportamentos das rotinas organizacionais, alguns autores discorrem sobre a relação entre as rotinas, normas e a conformidade organizacional como meio de promover legitimidade organizacional (FELDMAN e $\mathrm{MARCH}$, 1981). Além disso, as rotinas também foram estudadas sob a perspectiva do conflito e poder (NELSON e WINTER, 1982). Nesse sentido, Feldman e Pentland (2003) refletem que as rotinas organizacionais podem ser 
utilizadas como um "padrão" das atividades, reduzindo o conflito, dado que funciona como um consenso entre os envolvidos.

Em uma perspectiva de uma nova teoria de rotinas organizacionais, Feldman e Pentland (2003) consideram que a rotina é constituída por aspectos ostensivos, performativos e os artefatos. Esses elementos constituem a estrutura interna da rotina (PENTLAND e FELDMAN, 2005) e serão melhor discutidos nas próximas seções. Estudos apontam as rotinas como paradoxais, contribuindo tanto para estabilidade quanto para as mudanças na organização, neste caso, as pesquisas relacionadas a estrutura interna da rotina e suas interações ajudam a explicar esse fenômeno (PENTLAND e FELDMAN, 2005).

\subsection{1.}

\section{Aspecto ostensivo}

Latour (1986) apresenta o conceito de "ostensivo" sob a perspectiva do poder, mas Feldman (2000) observa a sinergia para o conceito dentro do universo das rotinas.

O aspecto ostensivo por vezes é confundido apenas como orientador do aspecto performativo (PENTLAND e FELDMAN, 2005). Contudo, para os autores, o ostensivo carrega a dinâmica de ser a referência generalizada da rotina, sua representação mental ou a noção da rotina, podendo ser utilizado pelos envolvidos como balizador, servindo para "orientar" e "explicar" o aspecto performativo. D'Adderio (2011) relembra que é comum que os envolvidos criem artefatos para tentar controlar e descrever a rotina em sua totalidade, confundindo, assim, o artefato e o aspecto ostensivo, que envolve muito mais que uma representação parcial (artefato), mas o abstrato da rotina (ostensivo). Os conhecidos procedimentos operacionais padronizados (Standard Operating Procedures - SOP) podem ser confundidos com o aspecto ostensivo, mas devem ser vistos como indicadores ou codificadores do ostensivo. (PENTLAND e FELDMAN, 2005).

Conforme Feldman e Pentland (2003) refletem, o aspecto ostensivo aparenta ser um padrão unificado da rotina. Contudo os autores salientam que esse conceito seria equivocado, dado que o ostensivo é composto também pela compreensão subjetiva dos participantes, considerando tanto a opinião de cada um quanto o papel em que atuam. Desta forma, os autores ainda exaltam que é provável que existam vários entendimentos do aspecto ostensivo dada a multiplicidade de envolvidos na rotina, pois mesmo que acessem as mesmas informações os sujeitos que participam da rotina possuem interpretações 
próprias. Essa visão também serve de suporte para os teóricos que estudam o poder de agência (PARMIGIANI e HOWARD-GRENVILLE, 2011) dos atores nas rotinas organizacionais.

\subsection{2.}

\section{Aspecto performativo}

Se o aspecto ostensivo se relaciona com a ideia da rotina, o aspecto performativo é a rotina na prática. Está relacionado a "pessoas realizando ações específicas em lugares e momentos específicos" (FELDMAN e PENTLAND, 2005). Os autores citados ainda ressaltam que, mesmo que as atividades ou processos sejam realizadas num contexto com regras que norteiam 0 movimento, o performativo ou a prática de uma determinada rotina possui caráter múltiplo e é constituída também por improvisação considerando os envolvidos, as ações tomadas por eles e as informações consideradas relevantes.

De forma recorrente, a organização, assim como no aspecto ostensivo, tenta criar artefatos que determinem como a prática deve ser realizada ou que tentam descrever como o performativo acontece de maneira detalhada e em sua integridade. Ainda que seja possível direcionar ou descrever o aspecto performativo da rotina, o resultado é limitado. Existe uma parte que fica em aberto, que dependente do contexto e dos participantes (FELDMAN e PENTLAND, 2005).

Não muito distante de um conceito de rotinas com características de inércia (HANNAN e FREEMAN, 1984), Feldman (2000) traz a luz aos movimentos de mudança e suas possibilidades no universo das rotinas organizacionais. Não menos importante que as mudanças influenciadas pelo aspecto ostensivo, é válido salientar que para a autora, a agência dos atores sobre a prática ou suas múltiplas interpretações frente ao performativo também podem resultar em mudanças nas rotinas.

\subsection{3.}

\section{Artefatos}

Versados como partes constituintes das rotinas, os artefatos são vistos como a expressão física da rotina organizacional (FELDMAN e PENTLAND, 2005). Na maioria das vezes os artefatos têm por objetivo descrever uma rotina, mesmo que de maneira limitada, como representação pode-se citar as regras, normas e procedimentos. Contudo, máquinas ou uma simples unidade de 
trabalho configuram como exemplos de artefatos (FELDMAN e PENTLAND, 2005). Apesar de ser uma representação física e visto como um resumo objetivo das rotinas, os artefatos são construídos a partir dos "entendimentos subjetivos" sobre eles (FELDMAN e PENTLAND 2003). Vale salientar que a subjetividade, a interpretação, o "olhar" são o elo entre os aspectos ostensivos e performativos que tentam ser codificados nos artefatos (FELDMAN e PENTLAND, 2003).

D'Adderio (2008) propõe colocar os artefatos como centro das rotinas. Para tanto introduz algumas perspectivas de estudo sobre os artefatos, uma corrente que propõe o artefato como limitador ou permissivo com relação as dinâmicas organizacionais e outra forte perspectiva sobre "humanos" e "nãohumanos" com poder de agência, capazes de persuadir e interagir. Para a autora, longe de serem "caixas-pretas" sem dinâmica e com características apáticas, os artefatos representam também o papel de atores juntos dos participantes na rotina organizacional.

Retomando os procedimentos operacionais padronizados (SOP), por vezes os artefatos como representação da rotina são descritos dessa forma na organização com o intuito de direcionar e assegurar que os sujeitos envolvidos sigam as ações determinadas (PENTLAND e FELMAN, 2008). Contudo, D'Adderio (2008) assegura que esses artefatos não são "neutros", mas que são parâmetros ou padrões de caráter exclusivo dos agentes envolvidos na sua construção e utilização. Para a autora, as pessoas incorporam seus conhecimentos, suas intenções, a bagagem que já carregam, a exemplo disso, considera-se as "melhores práticas", ou seja, artefatos que carregam experiências, conhecimentos dos envolvidos, tanto de usuários como dos que têm o papel de construir um artefato. Sendo assim, é oportuno falar dos artefatos como fortes agentes nas rotinas (D'ADDERIO, 2008) e como os envolvidos podem também decidir ignorá-los, mas que, na maioria das vezes, costumam seguir sem questionar (MACKENZIE, 2006; D'ADDERIO, 2008).

\subsection{4.}

\section{As inter-relações entre aspectos ostensivos, performativos e artefatos}

Considerando as discussões dos teóricos frente às rotinas organizacionais, os questionamentos sobre um comportamento de inércia ou como agentes de mudança, as relações dentro da a estrutura interna da rotina (PENTLAND e FELDMAN, 2005) podem ajudar a esclarecer os movimentos da rotina na organização. É oportuno ressaltar que as divergências e os consensos têm 
papéis importantes no processo de mudança da rotina e podem significar melhorias (FELDMAN, 2000).

Pentland e Feldman (2005) representam as rotinas como sistemas generativos (Figura 1) em que os artefatos tentam transcrever ou codificar os aspectos ostensivos e performativos, podendo restringir ou encorajá-los, dependendo da intenção dos envolvidos. Refletindo a partir de estudos anteriores, os autores elucidam que os artefatos podem funcionar como coletores de informações das rotinas, funcionando por vezes como "proxy" para o aspecto ostensivo, a exemplos das regras e normas formalizadas, ou como um banco de dados, funcionando como recurso para o aspecto performativo.

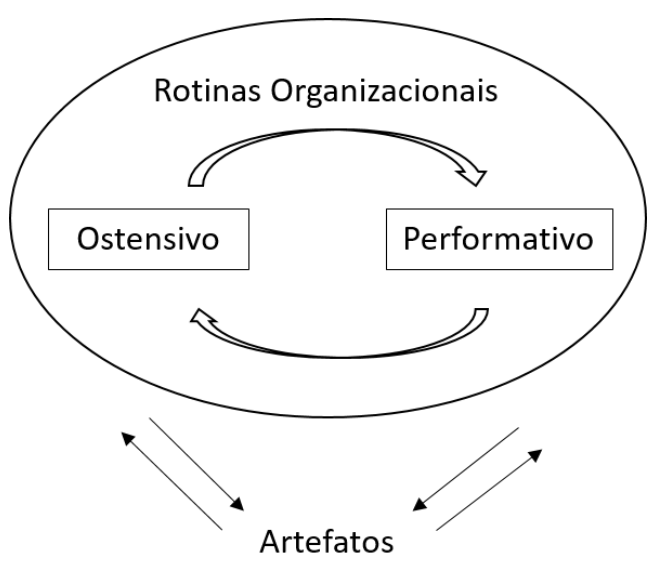

Figura 1: Rotinas organizacionais como sistemas generativos. Fonte: Adaptado de Pentland e Feldman (2005).

As relações entre esses elementos, vistos como estrutura interna da rotina (PENTLAND e FELDMAN, 2005), puseram em foco a força, ou mesmo o nível de interação entre esses componentes da rotina e, até que ponto a rotina pode ser uma fonte de mudança (FELDMAN e PENTLAND 2003). Partindo para a interação entre o aspecto ostensivo e o performativo, é importante salientar que ambos têm características múltiplas e dependem dos indivíduos envolvidos, de suas percepções e até do momento que entendem o início e fim da rotina (PENTLAND e FELDMAN, 2005). Os autores ainda relembram que a qualidade variável desses aspectos pode influenciar um ao outro; contestações podem impactar nos desempenhos e um contexto ou mesmo a maneira como um agente decide realizar a rotina pode impactar no aspecto performativo apresentando novas possibilidades. 
As interações entre os artefatos e o aspecto performativo podem se caracterizar por variações de relação de poder (PENTLAND e FELDMAN, 2005). D’Adderio (2008) pondera que normalmente os artefatos são construídos com o intuito de tentar direcionar as performances, mas que por vezes, o aspecto performativo pode ser incorporado aos artefatos, por exemplo, as "melhores práticas" advindas das experiências e do conhecimento dos atores envolvidos nas rotinas. Quando refletido o artefato frente ao aspecto ostensivo, por vezes ele pode ser confundido com o aspecto ostensivo, às vezes por sua proximidade ou pela intenção da alta administração em determinar e induzir como a rotina deve ser entendida ou vista, contudo, não é raro que haja divergências na compreensão tanto do ostensivo, quanto do artefato. (PENTLAND e FELDMAN, 2005).

Em suma, é importante considerar que as rotinas são fontes de mudança (FELDMAN, 2000), oportunidades para demonstrações de poder (PENTLAND e FELDMAN, 2005) e que os teóricos não devem subestimar o papel dos artefatos, dado que artefatos e rotinas podem coevoluir (D'ADDERIO, 2008). Ações de controle podem ser utilizadas para mudar o aspecto performativo; ações de reforço, como treinamentos, podem alterar o aspecto ostensivo; e alinhar os artefatos as mudanças desejadas podem influenciar ambos os aspectos. (PENTLAND e FELDMAN, 2005).

\section{2.}

\section{Controles internos}

O termo controle interno vem sendo definido quase que unicamente por profissionais e acadêmicos relacionados a auditoria. Contudo, o conceito vem sendo aperfeiçoado por entidades e órgãos reguladores nacionais e internacionais (SANCHES, 2007). Parte desse aperfeiçoamento foi estimulado pelos escândalos relacionados a fraudes corporativas em empresas que atuavam no mercado americano, a exemplo, cabe citar ENRON, XEROX, PARMALAT, entre outras empresas que tiveram seus casos noticiados na mídia internacional.

Em 2002, o governo americano sancionou a Lei Sarbanes-Oxley com o objetivo de fortalecer a confiança do mercado de capitais, fortalecer uma estrutura de controles internos, responsabilizando a alta administração pelo cumprimento dos controles, divulgação de suas insuficiências e relatórios financeiros (MAIA; DUEÑAS; ALMEIDA; MARCONDES; CHING, 2005). 
O Comitê de Procedimentos de Auditoria do Instituto Americano de Contadores Públicos Certificados, AICPA, Estados Unidos (Apud ATTIE, 2009, p. 148) define controles internos de uma maneira ampla, considerando o plano de organização e as providências tomadas pela organização a fim de resguardar ativos, conciliação e fidedignidade dos dados contábeis, implementação de atividades que favoreçam a eficiência operacional, bem como estimular a aquiescência às políticas estabelecidas pela administração. Attie (2009) levanta a questão de que a definição do AICPA, apesar de ampla para o conceito de controles internos, vislumbra a ideia de que o sistema de controles internos vai além dos conceitos ligadas às áreas de contabilidade e finanças.

O IBGC (2015) explica que os controles internos são construídos por controles gerais ou específicos. Salienta que existem metodologias ligadas a avaliação de riscos associados a controles que consideram o perfil de risco e a eficácia dos procedimentos que os monitoram.

Expondo a complexidade do conceito de controles internos, o Committee of Sponsoring Organizations of the Treadway Commission (2013), conhecido como COSO, define controle interno como um processo movido pela governança, pela administração e profissionais da organização, com o intuito de tentar possibilitar a realização de objetivos relacionados a eficácia e eficiências das operações; divulgação podendo englobar conceitos de confiabilidade; transparência; oportunidade e conformidade com leis e regulamentos aplicáveis. Segundo o Portal de Auditoria (2017) a estrutura de Controles Internos orientada pelo COSO é uma das mais utilizadas pelas companhias americanas, sendo indicada por estruturas como a SEC (Securities and Exchange Commission) dos EUA para adequação da Lei Sarbanes-Oxley nas empresas ou mesmo para FCPA (Foreign Corrupt Practices Act), a legislação americana que estabelece medidas para combater a corrupção.

Ainda sob a ótica do COSO (2013), o controle interno está dividido em 5 componentes que funcionam de maneira integrada:

- "Ambiente de controle": é a junção dos valores éticos, normas, processos, procedimentos estabelecidos e reforçados pela alta administração a fim apoiar a condução dos controles internos por toda a organização.

- "Avaliação de riscos": é um processo dinâmico que visa identificar e avaliar os riscos a realização dos objetivos estabelecidos pela organização. Neste componente serão considerados como os riscos serão gerenciados, tolerância, impactos oriundos do ambiente externo e 
interno, bem como qualquer circunstância que possa tornar um controle ineficaz.

- "Atividades de controle": São as políticas e os procedimentos que apoiam as ações necessárias para gerenciar riscos atenuar os objetivos estabelecidos. As atividades de controle podem ser classificadas como de prevenção e/ou detecção e podem ser desenvolvidas em todos os níveis da organização, como atividades de alçadas, conciliação, segregação de funções, revisões, entre outras.

- "Informação e comunicação": A informação serve de apoio para que a organização cumpra com os controles internos estabelecidos para o atingimento de seus objetivos. Os processos relacionados à comunicação são fluidos, interativos e devem permitir que os funcionários compreendam suas responsabilidades na estrutura de controles internos bem como sua importância.

- "Atividades de monitoramento": Essas atividades visam a avaliar a qualidade dos 5 componentes dos controles internos podendo ser realizadas com monitoramento contínuo das atividades, avaliações separadas, ou uma combinação destes. Os critérios utilizados para avaliar são estabelecidos por órgão normatizados, pela administração, pela estrutura de governança e as deficiências encontradas devem ser comunicadas a administração da organização e a estrutura de governança.

Os resultados são avaliados em relação a critérios estabelecidos pelas autoridades normativas, órgãos normatizadores reconhecidos ou pela administração e a estrutura de governança.

Com base nos 5 componentes, nas categorias de objetivos e na estrutura organizacional, o COSO (2013) estabelece uma ilustração em cubo, que retrata que a relação direta entre os objetivos, componentes e estrutura organizacional e a execução de princípios relacionados, podem possibilitar um controle interno eficaz. 


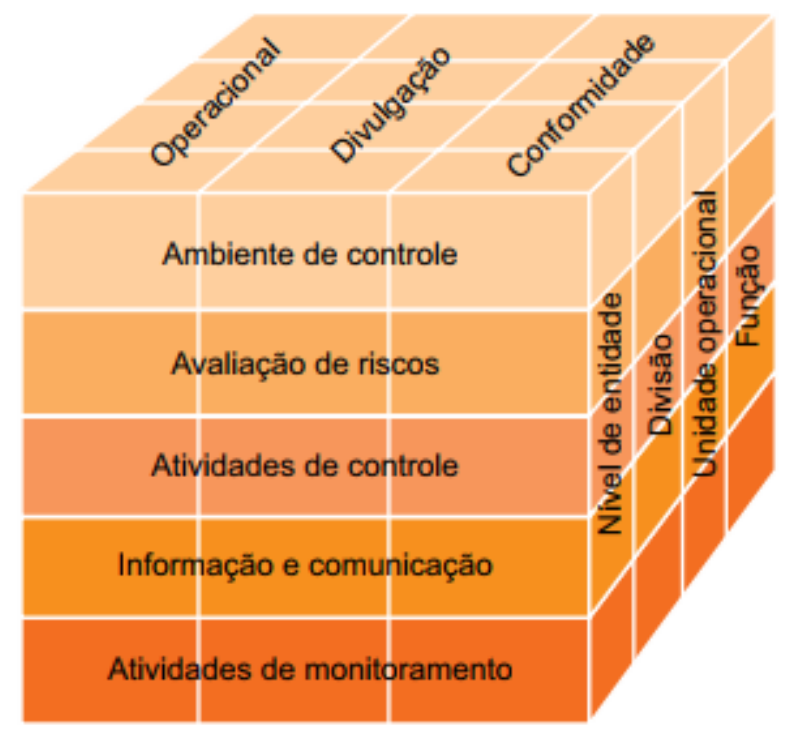

Figura 2: Elaborado pelo Committee of Sponsoring Organizations of the Treadway Commission.

O BACEN (1998) determinou para as instituições financeiras e outras instituições sob sua competência a implantação e implementação do sistema de controles internos. Numa publicação posterior, o BACEN (2009) exige que sejam considerados elementos relacionados ao ambiente de controle, gestão de riscos, controles, informações e comunicações, monitoramento e aperfeiçoamento e deficiências identificadas demonstrando uma semelhança pelo modelo desenvolvido pelo COSO.

Em consonância com o BACEN, a Superintendência de Seguros Privados (2004), órgão responsável por regular o mercado de seguros no Brasil, determinou na publicação da Circular $\mathrm{n}^{0}$ 249, o estabelecimento e implementação do sistema de controles internos para seguradoras, sociedades de capitalização e entidades abertas de previdência complementar. Nesta circular, a SUSEP (2004) dispõe sobre a responsabilidade da organização em estabelecer atividades, níveis e objetivos de controle, monitoramento, gestão dos riscos, procedimentos e formalização em políticas que estejam acessíveis a todos os funcionários. A publicação dessa normativa deu início ao processo de criação da área de Controles Internos nas seguradoras e o estabelecimento de atividades e procedimentos formalizados com relacionados ao tema. É dentro dessas atividades e rotinas de controles internos que esse estudo se concentra. 


\section{3. \\ O conceito de Accountability}

A palavra accountability é um termo na língua inglesa que carrega um conceito multifacetado. Contudo, sua tradução para a língua portuguesa carrega desafios, dado que, muitas das traduções ou conceituações reduzem a uma definição simples, que compromete o entendimento de sua complexidade.

No intuito de tentar apresentar alguns conceitos ou significados possíveis para accountability, este estudo inicia com definições de alguns dicionários.

"The quality of being accountable; liability to give account of, and answer for, discharge of duties or conduct; responsability, amensbleness. = accountableness." (MICHAELIS, 1988)

Neste dicionário, o conceito surge como responsabilidade ou responsabilização de alguém sobre algo que aconteceu. De acordo com o dicionário Oxford (1995) o termo accountability aparece como uma variação do termo accountable:

\footnotetext{
"required or expected to give an explanation of one's actions, expenditure, etc; responsible: Who are you accountable to in the organization? - accountability: the accountability of local government to Parliament - proposals for greater accountability on the parto $f$ the police."
}

Neste caso, o termo carrega um significado de prestação de contas por ações ou despesas, responsabilidade. Já para o Cambridge Dictionary (2018) a definição de accountability é a seguinte:

\footnotetext{
"A situation in which someone is responsible for things that happen and can give a satisfactory reason for them: The organization suffers from a lack of accountability. greater/increased/more accountability The public has been demanding greater accountability from lawmakers.".
}

Com base nos dicionários consultados que definem o termo, de maneira geral, o termo se concentra em prestação de contas ou responsabilidade por algo, muitas vezes, como exemplifica o dicionário de Oxford (1995) e discute Campos (1990), ligados à questão de administração pública.

Considerando os dicionários de tradução inglês-português Michaelis (1988) e Collins (1991) a tradução de accountability é exposta como responsabilidade, ou para o termo accountable a tradução disposta é referente aos adjetivos responsável, explicável, justificável. 
Fazendo uma análise mais analítica, Koppell (2005) apresenta o conceito de accountability por meio de cinco dimensões: transparência, responsabilização, controlabilidade, responsabilidade e capacidade de resposta. Para cada dimensão, o autor determina um questionamento crítico correspondente que, em sua visão, equivale a uma extensão do conceito de accountability na prática.

\begin{tabular}{|l|l|}
\hline \multicolumn{1}{|c|}{ Dimensões de Accountability } & \multicolumn{1}{c|}{ Questões Chave } \\
\hline Transparência & $\begin{array}{l}\text { A organização revela os seus dados de } \\
\text { performance? }\end{array}$ \\
\hline Responsabilização ("Liability") & $\begin{array}{l}\text { A organização enfrenta as consequências } \\
\text { pela sua performance? }\end{array}$ \\
\hline Controlabilidade & $\begin{array}{l}\text { A organização faz o que é desejável pelas } \\
\text { instâncias superiores? }\end{array}$ \\
\hline Responsabilidade & A organização segue as regras e normas? \\
\hline $\begin{array}{l}\text { Capacidade de Resposta } \\
\text { ("Responsiveness") }\end{array}$ & $\begin{array}{l}\text { A organização atende às principais } \\
\text { expectativas (demandas/necessidades)? }\end{array}$ \\
\hline
\end{tabular}

Figura 3: Adaptado de Koppell (2005).

A transparência, primeira das dimensões do conceito accoutability na visão de Koppell (2005), é caracterizada como o "o valor literal" da accountability. Para o autor, uma organização responsável deve explicar suas ações, independente dos seus erros. Em uma organização, a transparência é um instrumento de avaliação do desempenho organizacional e exige informações verdadeiras a serem disponibilizadas aos stakeholders. (KOPPELL, 2005). Desta forma, facilmente é compreensível a questão chave determinada pelo autor relacionada a essa dimensão: "A organização revela os fatos do seu desempenho? ".

$\mathrm{Na}$ dimensão relacionada a responsabilização, Koppell (2005) relaciona a questão de assumpção das consequências pelas ações empreendidas, pelo desempenho da organização. Seja, pela punição, no caso dos erros, seja pela recompensa, no sucesso. A controlabilidade gira em torno do controle. $\mathrm{O}$ autor utiliza um exemplo de que se alguém pode induzir o comportamento de outro, diz-se que esse alguém controla o outro - e o outro é responsável por esse alguém. Essa questão diz respeito a seguir os objetivos traçados pelos gestores da organização, de um controle sobre seguir a estratégia ou as determinações dos gestores. O que, de certa forma, já apresenta uma ligação com a dimensão seguinte apresentada por Koppell (2005), responsabilidade. Nessa dimensão, o conceito de accountability está ligado a fidelidade a normas, leis, padrões. Diferente da anterior o autor expõe que a limitação nesta concepção é 
determinada pelas normas e não pelas determinações dos gestores. Quanto a última dimensão, segundo Koppell (2005) está relacionada a cumprir com a expectativa tanto de demanda quanto de necessidade por parte dos clientes, caso contrário a organização pereceria.

A discussão que Koppell (2005) está relacionada a qual concepção de accountability se considera para avaliar uma organização, por exemplo. Como o conceito carrega múltiplas concepções, a dificuldade reside com base em qual concepção os atores de baseiam para avaliar o que seria uma organização ou mesmo uma rotina carregada de accountability.

De maneira semelhante, Campos (1990) também considera a accountability como um conceito e não como uma simples palavra. As preocupações da autora estão ligadas as questões políticas e sociais brasileiras e a ausência de um conceito de accountability no Brasil. A autora atribui parte da ausência de um conceito formado, a uma pobreza política e a um fraco tecido institucional, a época de seu artigo, muito incômodo, sendo o período vivido tão próximo a ditadura militar. Pinho e Sacramento (2008) resolveram fazer uma nova reflexão frente às considerações de Campos (1990) à procura de um conceito de accountability no Brasil, apesar de reconhecerem uma evolução, concluem que ainda está muito longe de se estabelecer uma cultura de accountability. Contudo, reúnem um significado de accountability que envolve "responsabilidade objetiva e subjetiva, controle, transparência, obrigação de prestação de contas, justificativas para as ações que foram, ou deixaram de ser empreendidas, premiação e/ou castigo" (PINHO e SACRAMENTO, 2008).

O presente estudo utilizou o conceito de Pinho e Sacramento (2008) para suportar a pesquisa, dado que reúne tantas concepções possíveis de accountability. Desta forma, ainda que não tão reconhecido pelo grupo envolvido na pesquisa, servisse de ilustração e suporte para um conceito com características tão variadas. 


\section{3 \\ Procedimentos metodológicos}

Esse capítulo tem como objetivo apresentar e justificar a decisão de utilizar a metodologia escolhida para o presente estudo. O capítulo está dividido em seções que tratam dos aspectos epistemológicos e ontológicos, o tipo de pesquisa e sua justificativa de escolha, bem como a coleta de dados, os respectivos procedimentos de tratamento e análise e, por fim, as limitações do estudo.

\section{1.}

\section{Aspectos epistemológicos e ontológicos}

No presente estudo, os aspectos ontológicos tiveram como pressuposto uma realidade subjetiva e múltipla, ou seja, a realidade não é única e nem fixa e é construída por meio de interpretações baseadas nas interações no mundo (GREEN, 2005). Neste caso, a partir das diferentes percepções dos envolvidos no estudo frente a um fenômeno em particular (MARTON e BOOTH, 1997). Admitindo uma ontologia não-dualista, na qual a realidade é considerada tal qual é vivenciada, o foco da estratégia de pesquisa utilizada esteve centrado nos aspectos semelhantes e distintos frente a um fenômeno em comum bem como suas relações (ARKELIND, 2005). Os aspectos epistemológicos se mantiveram com caráter subjetivista (VERGARA e CALDAS, 2005), no qual as interações entre o pesquisador e os entrevistados criam entendimentos subjetivos (GREEN, 2005).

Em resumo, a metodologia utilizada permite que os indivíduos envolvidos na pesquisa descrevam suas percepções com relação a um fenômeno específico. Contudo, a análise é realizada de uma forma que transpõe indivíduos e contextos (GREEN, 2005), considerando um conjunto coletivo de significados evoluindo a análise em um contraponto de concepções (ARKELIND, 2005).

Desta forma, este estudo utilizou falas para justificar o espaço de resultados que emergiu dos relatos. É importante salientar a utilização de exemplos nas falas selecionadas, em virtude não só da identificação no conjunto de significados, mas, também, a fim de assegurar que a definição do termo 
accountability apresentado aos entrevistados não influenciou os depoimentos. A decisão do pesquisador em realizar a leitura de um conceito base de accountability aos entrevistados, advém da preocupação elucidada por Campos (1990) com a ausência de reconhecimento tanto da palavra quanto do conceito no Brasil. Ademais, mesmo em sua língua materna, o termo carrega múltiplos significados (KOPPELL, 2005). Somados os dois argumentos, o autor reconheceu que deixar de apresentar um conceito poderia impactar na condução e nos resultados da pesquisa.

\section{2.}

\section{Tipo de pesquisa}

Partindo de uma abordagem interpretativista, o presente estudo pretendeu verificar por meio de uma pesquisa qualitativa, as percepções de mundo dos envolvidos na pesquisa. Vergara e Caldas (2005) refletem que o paradigma interpretativista carrega a inquietude em buscar compreender a experiência subjetiva das pessoas.

Creswell (2010) caracteriza a pesquisa qualitativa como tendencialmente realizada no ambiente em que os participantes experimentam o fenômeno, por meio de um processo indutivo, centrado nos significados que os entrevistados vivenciam o problema de pesquisa. Ainda sobre o autor, ele complementa informando que o pesquisador busca construir um mapa complexo frente ao fenômeno investigado, interpretando os dados com base no que veem, escutam e compreendem, conduzindo a análise da pesquisa com base nos dados que emergem, valorizando a interpretação a partir dos significados revelados pelos dados.

A pesquisa foi conduzida em um ambiente organizacional, no período de 09/08/2017 a 09/10/2017, e foi baseada na prática dos profissionais envolvidos nas rotinas de controles internos em suas respectivas áreas de negócio. A intenção foi investigar como eles compreendiam a incorporação da accountability das rotinas organizacionais envolvidas com os controles internos. Neste estudo, diante das características presentes no problema de pesquisa, a metodologia selecionada foi a fenomenografia. 


\section{3.}

\section{Abordagem da pesquisa fenomenográfica}

A palavra fenomenografia é constituída em sua etimologia por dois termos: fenômeno e grafia. $O$ termo fenômeno tem sua origem no latim PHAENOMENON, do grego PHAINOMENON, "o que é visto, o que surge aos olhos", de PHAINESTHAI, "aparecer", relacionado com PHOS, "luz", já o sufixo grafia, é derivado do grego GRAPHEIN "escrever". (ORIGEM DA PALAVRA, 2018). A etimologia da palavra fenomenografia serve como ponto de partida para entender o cerne dessa abordagem de pesquisa. Sandberg (2000) apresenta a abordagem fenomenográfica discorrendo, inicialmente, sobre sua origem datada no final dos anos 70 a partir de uma pesquisa na área de educação na Suécia. Marton (1981) foi um dos primeiros autores a descrever a abordagem e explica que o objetivo central da fenomenografia é orientar o pesquisador a concentrar sua análise nas várias concepções, percepções e vivências da realidade a partir do "pensamento" ou da "experiência" do sujeito. De maneira mais característica, Marton e Both (1997) definem como foco da fenomenografia, as diferentes maneiras de experimentar um fenômeno específico.

Caracterizada por admitir uma ontologia não dualista (ARKELIND, 2005), conforme descrito na seção dedicada ao aspecto ontológico (seção 3.1), essa abordagem está centrada na experiência de mundo das pessoas, preocupada em analisar qualitativamente diferentes concepções e suas relações a respeito de um mesmo fenômeno. Conforme reflete Fernandes (2005), a fenomenografia se diferencia da fenomenologia, pois conduz sua investigação sob o olhar da reflexão sobre a vivência. A fim de demonstrar a diferença entre fenomenologia e fenomenografia, Marton (1981) fez um comparativo entre as duas visões frente a uma possível pesquisa sobre "poder político". O autor, por meio de um exemplo, ilustra que um estudo fenomenológico sobre o poder político se caracterizaria por algo encontrado a respeito do poder político a partir de uma investigação fenomenológica, já a fenomenografia sobre o "poder político", seria orientada por qualquer coisa percebida, compreendida, vivenciada frente ao "poder político", ou seja, qualquer opinião, ou conceituação do entrevistado sobre o fenômeno é considerada pela abordagem fenomenográfica. 
O resultado dos diferentes significados e de suas relações, considerando as semelhanças e diferenças entre si, trazidos pelos entrevistados constrói o que que os estudiosos dessa abordagem chamam de espaço de resultados (pool of meanings). Esse espaço de resultados é composto pelas categorias descritivas, vistas como concepções do fenômeno, e das dimensões que explicam as categorias (ARKELIND, 2005).

O presente trabalho tem por objetivo descrever o conjunto de significados de como a accountability é percebida nas rotinas de controles internos a luz de qualquer compreensão ou significação dos entrevistados conforme preconiza a fenomenografia. O pesquisador buscou não incluir suas percepções a partir do fenômeno, nem interferir nas concepções relatadas pelos entrevistados, visando proteger o objetivo da pesquisa, que é a relação entre o grupo e o fenômeno (BOWDEN, 2005).

\section{4 .}

\section{A fenomenografia e suas relações}

Esta seção busca esclarecer a respeito das relações, vivências, interações desenvolvidas pela fenomenografia. Bowden (2005) estabelece um modelo (Figura 4) que propõe trazer luz a essas relações para que o objetivo da fenomenografia seja esclarecido e coerência da abordagem seja esclarecida.

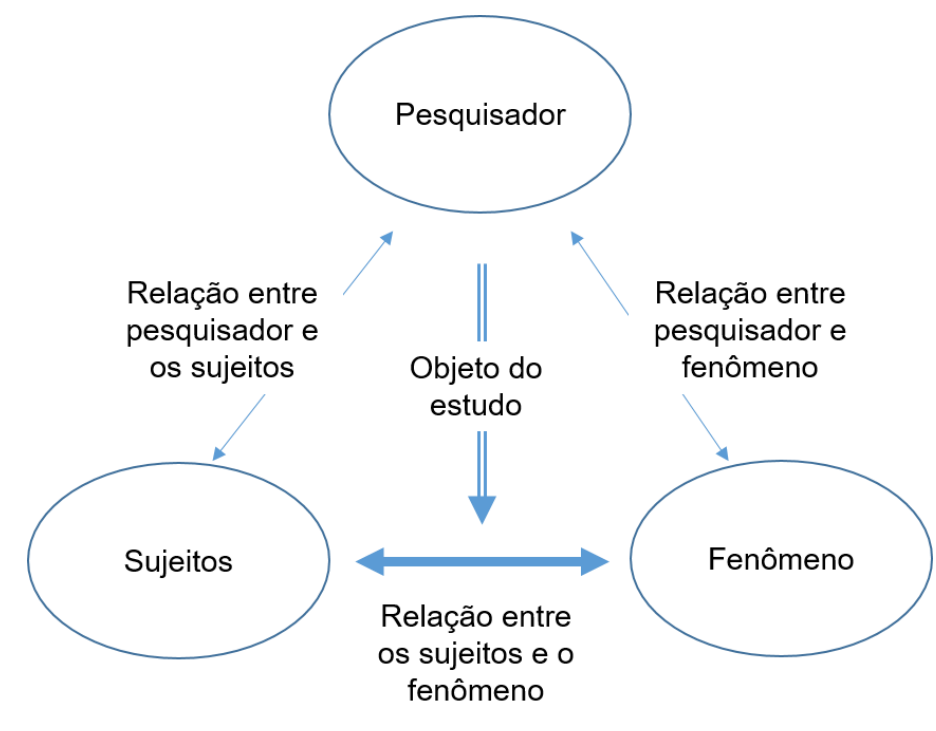

Figura 4: As relações na fenomenografia. Fonte: BOWDEN, 2005. 
Construir uma reflexão a respeito das relações na fenomenografia apresenta esta abordagem metodológica de maneira mais detalhada e considerando algumas preocupações que fenomenógrafos consideram na aplicação de suas pesquisas. Bowden (2005) aborda em sua representação gráfica (Figura 4) como os aspectos relacionais da fenomenografia: pesquisador, entrevistados e fenômeno se relacionam entre si. Contudo, esta metodologia condiciona em seus estudos diminuir ao máximo a relação entre pesquisador e os entrevistados e a relação entre o pesquisador e o fenômeno para pôr sua luz frente ao objetivo real do estudo que é a relação entre os sujeitos e o fenômeno.

As relações entre o pesquisador e os sujeitos ou mesmo entre o pesquisador e o fenômeno, visto que, o pesquisador tem a sua forma de ver o fenômeno são minimizadas tanto na condução das entrevistas, quanto na análise dos dados. É essencial que as perguntas sejam construídas com base na relação "sujeito-fenômeno" e os comentários ou adições do pesquisador se restrinjam apenas a esclarecimentos sobre que o entrevistado relatou ou para solicitar mais informações, ou exemplos, com único objetivo que obter o máximo de significados possíveis vivenciados pelo grupo envolvido ao fenômeno. O pesquisador não deve fazer qualquer comentário de julgamento na entrevista ou adicionar opiniões ao conjunto de significados no momento da análise (BOWDEN, 2005).

Face ao disposto, é oportuno ressaltar que as relações "sujeitosfenômeno" são influenciadas pela forma como esse sujeito entende esse fenômeno. Dado que o método pretende identificar as diferentes maneiras de vivenciar o fenômeno, Marton e Booth (1997) entendem essencial considerar a seguinte questão: "o que é preciso para experimentar algo de uma determinada maneira?". Para responder essa pergunta, os autores descrevem que a experiência é vivenciada a partir de aspectos estruturais e referenciais, dependentes entre si. $\mathrm{O}$ aspecto estrutural trata de discernir algo (todo) a partir do seu contexto, mas também é preciso discernir as partes, suas relações entre si e com o todo. Já o aspecto referencial diz respeito a ver algo como particular. O aspecto estrutural conjectura discernir o todo do contexto, mas para isso é preciso atribuir significado ao todo, esse é o aspecto referencial. Os dois aspectos estão ligados no momento em que algo é vivenciado e a maneira como os sujeitos experimentam o fenômeno em um determinado momento vai depender de como os aspectos são reconhecidos (MARTON e BOTH, 1997). 
Sendo assim, este estudo se preocupa em desenvolver uma análise sobre os trechos baseados nos relatos das entrevistas em busca de identificar os significados que predominam no grupo de entrevistados, observando as concepções e as dimensões explicativas considerando suas características e relações.

\section{5.}

\section{Justificativa da abordagem da pesquisa}

A fenomenografia, como já refletido em alguns dos principais estudos relacionados ao tema (ARKELIND, 2005; MARTON, 1981; MARTON e BOOTH, 1997), tem por objetivo identificar as diferentes maneiras que determinados sujeitos experimentam o fenômeno estudado. A abordagem fenomenográfica subsidia ao pesquisador possibilidades de investigar a experiência coletiva dos fenômenos de maneira abrangente, considerando as diversas maneiras de vivenciar o fenômeno reveladas pelos relatos, quais concepções são apresentadas, experimentadas ou compreendidas pelos sujeitos (SANDBERG, 2000).

Tendo em vista que o presente estudo é focado nas experiências os profissionais envolvidos nas rotinas de controles internos e busca explorar e interpretar as diferentes concepções de accountability nas rotinas de controles internos por meio de uma pesquisa qualitativa, a abordagem fenomenográfica pareceu ao pesquisador a mais adequada frente ao problema de pesquisa. Adicionalmente, visto que a fenomenografia pretende mapear as relações entre os diferentes significados ou maneiras de vivenciar o fenômeno (ARKELIND, 2005), essa abordagem trouxe uma visão holística frente aos relatos, suportando o objetivo de pesquisa.

\section{6.}

\section{Coleta de dados}

Os dados coletados nesta pesquisa foram oriundos de entrevistas semiestruturadas com profissionais envolvidos nas rotinas de controles internos de várias áreas de atuação, em diferentes posições, em uma seguradora localizada no Rio de Janeiro. Os entrevistados descreveram suas percepções de como a accountability é incorporada nas rotinas de controles internos, por meio da questão central e dos exemplos e reflexões estimulados pelas perguntas de desenvolvimento de experiências e pelas perguntas acessórias. 


\section{7. \\ Seleção dos sujeitos}

Os sujeitos selecionados foram intencionalmente os profissionais denominados agentes de controles internos pela organização. Em virtude de o estudo ter sido desenvolvido com base nas rotinas de controles internos, o perfil desses profissionais pareceu mais próximo ao fenômeno investigado nestas rotinas organizacionais. Os agentes de controles internos estão presentes em várias áreas da organização e são indicados por seu gestor direto para ser uma espécie guardião de controles internos dentro da área em que atua. É oportuno salientar que esses profissionais fazem parte das áreas comuns da organização e desempenham atividades relacionadas a estas e não estão diretamente ligados à área de Controles Internos. Contudo, pela característica dos agentes de controles internos, esses profissionais possuem conhecimento sobre legislações e boas práticas relacionadas à governança e participaram de treinamentos que tratam de conceitos de compliance e controles internos.

A fim de atingir o critério mínimo para variação de sujeitos conforme sugere Bowden (2005), foram selecionados 20 agentes de controles internos, dentre os 21 existentes. O pesquisador optou por entrevistar somente os 20 sujeitos adequados ao critério, em virtude da indisponibilidade de um dos entrevistados. Vale ressaltar que a seleção dos agentes de controles internos para esta pesquisa foi possível, pois os entrevistados compunham critérios iniciais de variedade: 1) gêneros distintos; 2) idades diversas; 3) formações diversas; 4) diferentes cargos na organização; 5) diferentes áreas de atuação; 6) variação no tempo de experiência profissional e 7) envolvimento nas rotinas de controles internos.

Os critérios estabelecidos propuseram além do envolvimento com as rotinas de controles internos, garantir que a análise pudesse avaliar a percepção de gêneros distintos, idades diferentes e variação no tempo profissional a fim de perceber possíveis entendimentos relacionados a experiência profissional. Também consideraram se as percepções poderiam variar conforme formação e nível hierárquico e buscou inserir as diferentes áreas da organização para perceber eventuais percepções baseadas na área de atuação.

No quadro 1, é possível identificar o detalhamento das características dos sujeitos que participaram da pesquisa. 


\begin{tabular}{|c|c|c|c|c|c|c|}
\hline Gênero & Idade & Formação & Cargo atual & $\begin{array}{l}\text { Tempo de } \\
\text { experiência }\end{array}$ & \begin{tabular}{|l|} 
Tempo na \\
empresa
\end{tabular} & Área de atuação \\
\hline Feminino & 37 & Ciências Contábeis & Consultora de Processos & 17 anos & 11 anos & Sinistros \\
\hline Masculino & 36 & $\begin{array}{l}\text { Administração com ênfase em seguro } \\
\text { e previdência }\end{array}$ & Supervisor de Indenização Integral & 12 anos & 11 anos & $\begin{array}{l}\text { Sinistros - } \\
\text { Indenização Integral }\end{array}$ \\
\hline Masculino & 37 & Administração & Coordenador de Indenização Integral & 19 anos & 15 anos & $\begin{array}{l}\text { Sinistros - } \\
\text { Indenização Integral }\end{array}$ \\
\hline Masculino & 36 & Administração e gestão de seguros & Supervisor de Produto & 17 anos & 12 anos & Produto \\
\hline Masculino & 50 & Matemática & Coordenador Financeiro & 29 anos & 25 anos & Financeiro \\
\hline Masculino & 42 & Administração & Coordenador de administração & 20 anos & 6 anos & Administrativo \\
\hline Masculino & 44 & Ciências Contábeis & Analista de Controle de Gestão Sr. & 24 anos & 11 anos & Controle de Gestão \\
\hline Masculino & 33 & $\begin{array}{l}\text { Engenharia Elétrica com ênfase em } \\
\text { sistemas e computação }\end{array}$ & Analista de Governança de TI Sr. & 13 anos & 2 anos & $\mathrm{TI}$ \\
\hline Masculino & 55 & História & Supervisor de SAC & 36 anos & 12 anos & Atendimento \\
\hline Masculino & 41 & Administração & Coordenador de Processos de Emissão & 19 anos & 15 anos & Emissão \\
\hline Masculino & 57 & Ciências Contábeis & Coordenador de Contabilidade & 40 anos & 24 anos & Contabilidade \\
\hline Feminino & 31 & Administração com ênfase em Seguro & Técnico de Seguros PI & 15 anos & 10 anos & Produto \\
\hline Feminino & 51 & Administração & Coordenadora de Emissão & 30 anos & 20 anos & Emissão \\
\hline Masculino & 31 & Gestão de Seguros (em andamento) & Supervisor de Indenização Parcial & 11 anos & 9 anos & $\begin{array}{l}\text { Sinistros - Indenização } \\
\text { Parcial }\end{array}$ \\
\hline Feminino & 39 & Direito & Coordenadora de Operações de RH & 20 anos & 4 anos & Recursos Humanos \\
\hline
\end{tabular}

Quadro 1: Características dos sujeitos que participaram da pesquisa

Fonte: Elaborado pela autora 


\section{8.}

\section{Formulação do roteiro de entrevistas}

O roteiro de entrevistas (Apêndice I) foi construído de maneira semiestruturada. Teve início com uma breve introdução sobre o objetivo da pesquisa e seguiu subdividida em quatro blocos: questões introdutórias, questão central, questões de desenvolvimento de experiências e perguntas acessórias.

O propósito da questão introdutória "poderia me falar qual a sua formação e tempo de experiência profissional? " foi colher dados para compor os critérios de seleção da amostra. Em seguida, o entrevistado foi estimulado a falar de sua carreira profissional e as principais atividades desenvolvidas por ele em sua trajetória para agregar mais subsídios à caracterização dos entrevistados, mas, sobretudo para que o sujeito se sentisse mais à vontade em relação a entrevista. Além disso, foi perguntado ao entrevistado sobre "o que é controle interno para ele", com o intuito de verificar qual o entendimento que os sujeitos envolvidos na rotina de controles internos têm sobre o conceito, se ele faz alguma ligação com outros conceitos, como o de compliance, por exemplo.

Segundo Creswell (2010), a questão central pode ser caracterizada como vasta e centrada na exploração de um fenômeno. Desta forma, a pergunta central deste estudo buscou compreender como os entrevistados entendem accountability nas rotinas de controles internos. Por se tratar de um termo apresentado na língua inglesa e que, conforme Pinho e Sacramento (2008) discorrem, carrega um conceito, e não uma tradução pura e simples para o português, o pesquisador optou por fazer uma leitura inicial do conceito fornecido por Pinho e Sacramento (2008) antes da pergunta central. A questão central que retratou o problema de pesquisa foi "como você percebe que a accountability é incorporada nas rotinas de controle interno?" e se apresenta de forma ampla a fim de estimular a reflexão dos entrevistados frente ao fenômeno.

A fim de garantir que os entrevistados não se prenderiam de maneira "fixa" ao conceito de accountability lido pelo pesquisador, foram adicionadas perguntas de desenvolvimento de experiências, nas quais os respondentes usaram exemplos para exprimir e aprofundar as respectivas percepções frente ao fenômeno investigado. O pesquisador ainda considerou nas perguntas quando os entrevistados entendem que houve favorecimento ou dificuldade em acontecer a accountability nas experiências relacionadas, a fim de perceber eventuais subsídios que reforçassem suas concepções primárias e estimular que os entrevistados refletissem sobre algumas apresentações do fenômeno. 
Considerando as experiências vividas pelo entrevistado, o pesquisador questiona as vivências exemplificadas significaram para o entrevistado, a fim de atingir a profundidade e complexidade nas reflexões dos envolvidos na pesquisa.

Como recurso complementar, a pergunta acessória final solicitou ao entrevistado que em resumo, ele descrevesse o que a accountability, no conceito das rotinas de controle interno, significou para ele; uma tentativa de retomar o conceito com base nas experiências que o entrevistado vivenciou e discorreu durante a entrevista.

Ao final, o roteiro previu um espaço para que o entrevistado pudesse expor considerações ao assunto abordado ou a outras questões que não foram faladas.

\section{9.}

\section{Condução das entrevistas}

No total foram realizadas 22 entrevistas, todas presenciais, realizadas na no segundo semestre de 2017, mais precisamente no período de 09/08/2017 a 09/10/2017. Para análise final, foram consideradas 20 entrevistas, tendo em vista que duas das entrevistas serviram apenas como balizadoras na construção do roteiro, fornecendo subsídios aos ajustes necessários. Todas as entrevistas foram gravadas e somaram um total de 12 horas e 56 minutos, com duração média de 35 minutos, com mínimo de 22 minutos e máximo de 52 minutos. Os convites foram realizados pessoalmente, explicando-se qual o objetivo da pesquisa e informando que esta estava autorizada pela organização. Apesar da necessidade de remarcações em determinadas situações em que o entrevistado se viu indisponível, dado que as reuniões foram marcadas no ambiente físico da organização, todos os convidados aceitaram e compareceram à entrevista.

Foi possível identificar que alguns entrevistados inicialmente ficaram preocupados em responder algo incorreto e por alguns momentos o pesquisador viu a necessidade de tranquilizá-lo sobre o fato de que não haveria julgamentos de "certo ou errado" por parte da organização ou do pesquisador frente as suas respostas.

Seguindo as etapas das entrevistas, após breves cumprimentos e contextualização do problema de pesquisa, as perguntas introdutórias referentes à experiência profissional foram enriquecedoras dado que o entrevistado construiu um espaço de tempo com atividades desenvolvidas e que, posteriormente, pode basear alguns exemplos citados na entrevista. A pergunta introdutória centrada no "o que é" controle interno, serviu de ponte para a citação 
do conceito de accountability utilizado no roteiro de pesquisa e em seguida para o questionamento sobre "como eles percebem" que a accountability é incorporada nas rotinas de controles internos. Por vezes, os entrevistados consideraram controles internos como área, ou como rotinas ou como o próprio conceito de accountability. Desta forma, o pesquisador buscou solicitar exemplos de maneira recorrente, alguns momentos durante a fala ou após as conclusões, a fim de que possibilitasse a emersão do real conjunto de significados frente ao fenômeno abordado, reflexões sobre as dificuldades e favorecimentos da ocorrência da accountability com base nos exemplos citados.

É oportuno ressaltar que durante a entrevista, o pesquisador buscou deixar os entrevistados a vontade para expor suas considerações e concepções de maneira espontânea, sem julgamentos sobre os conceitos envolvidos. Ademais, os entrevistados puderam responder sem preocupações quanto a duração de suas respostas. As perguntas acessórias foram utilizadas durante a entrevista, conforme os relatos demonstrassem a necessidade de maiores explicações frente as considerações apresentadas.

\subsection{0.}

\section{Tratamento e análises dos dados que emergem do campo}

\subsection{1.}

\section{Tratamento dos dados}

Os 20 relatos apreciados na análise totalizaram 347 páginas transcritas. Como movimento inicial, o pesquisador desfez qualquer referência na entrevista que relacionasse o entrevistado. Os nomes foram retirados e substituídos por números, e os trechos selecionados não contemplam questionamentos pessoais ao pesquisador a fim de garantir que o estudo afastasse da análise qualquer relação de proximidade. Entendeu-se esse procedimento como oportuno, tendo em vista o fato de que o pesquisador integra o mesmo ambiente organizacional no qual os entrevistados fazem parte. Conforme orienta Arkelind (2005), apesar de o pesquisador compor a área de Controles Internos, houve uma preocupação em manter a mente aberta, sem estabelecer preconcepções baseadas em um conhecimento anterior, nem precipitar um parecer frente às categorias descritivas, buscando refazer o pensamento conforme a emersão dos dados baseados nas reflexões e discussões apresentadas pelos entrevistados organizando-as num conjunto de significados. 
Marton (1981) esclarece que na metodologia fenomenográfica as concepções e as maneiras de compreender emergidas não são avaliadas como qualidades individuais. Conforme Akerlind (2005) explica, o foco desta pesquisa é investigar o conjunto de significados revelado pelo grupo de entrevistados em conjunção, e não o conjunto de significados de cada entrevistado dentro do grupo, considerando semelhanças e diferenças para estabelecer as categorias descritivas da experiência coletiva frente ao fenômeno.

Conforme Marton e Both (1997) preconizam, o presente estudo considerou como elementos de qualidade da análise as seguintes características essenciais: as categorias descritivas devem apresentar uma maneira específica sobre como cada uma entende o fenômeno; deve existir uma relação entre as categorias, de forma que se apresentem hierarquicamente inclusivas e os resultados sejam ponderados de forma a apresentar o menor número de categorias.

\subsection{2.}

\section{Análise dos dados}

A análise dos dados durou cerca de dois meses e buscou inspiração em estudos desenvolvidos por Marton (1981), Marton (1986), Marton e Booth (1997), Arkelind (2005), Bowden (2005), Figueira (2016) e Jardim (2017). Inicialmente, as entrevistas foram desvinculadas das referências aos entrevistados a fim de garantir a dissociação pessoal na análise. Em seguida, as 20 transcrições foram lidas, em sua totalidade, cerca de seis vezes cada uma, com o objetivo de identificar de maneira descontruída os significados preliminares sobre o fenômeno. A partir dessa leitura, para cada característica identificada, foram selecionados trechos correspondentes a fim de justificar a avaliação inicial da leitura e suportar o pesquisador na próxima roda de leituras.

Em uma segunda rodada de leitura, todas as entrevistas foram lidas novamente, sem nenhuma identificação ou observação carregada das leituras anteriores. Os significados identificados nessa segunda rodada foram selecionados para que, em seguida, o pesquisador realizasse uma comparação entre o resultado da segunda rodada de leitura com a primeira. O objetivo foi identificar se as percepções listadas pelo pesquisador inicialmente foram mantidas ou se algo novo emergiu frente à releitura do pesquisador. A fenomenografia põe luz à descrição e analisa a compreensão das experiências (MARTON, 1981). Desta forma, a partir do comparativo, entre o resultado da primeira e segunda etapas de leituras, surgiu o primeiro conjunto de significados (pool of meanings) dos entrevistados face ao problema de pesquisa. Inspirado 
em Akerlind (2005), o pesquisador buscou olhar para os trechos selecionados e se perguntar "o que" isso me diz sobre a forma como ele entende a accountability nas rotinas de controles internos. Como salientado na subseção sobre a condução das entrevistas, foram solicitados exemplos recorrentemente, a fim de subsidiar a análise no "como" o grupo de entrevistados compreendiam o fenômeno objeto desta pesquisa. Sendo assim, os trechos selecionados estão permeados de exemplos compatíveis entre si em suas respectivas categorias. Os trechos denominados por números foram relidos e comparados entre si a fim de verificar as semelhanças e diferenças entre eles com o objetivo de delimitar e caracterizar cada categoria (MARTON, 1986).

Em um terceiro momento, houve uma releitura de todas as entrevistas e dos fragmentos selecionados para certificar que os trechos escolhidos demostravam a essência da experiência coletiva de cada categoria e para que as dimensões explicativas pudessem ser organizadas. Em alguns momentos das leituras e das comparações, alguns trechos migraram entre um conjunto e outro. Nesta fase foram identificadas semelhanças significativas entre duas dimensões explicativas baseadas nas abordagens dos profissionais entrevistados, optando o pesquisador por conjugá-las. Nesse instante, o pesquisador buscou descrever com base no conjunto de significados emergidos pequenas descrições tanto das categorias descritivas, quanto das dimensões explicativas construindo a representação do espaço de resultados. Este processo buscou consolidar os significados encontrados, bem como as características que assemelhavam ou diferenciavam as categorias. O procedimento se mostrou interessante, visto que o pesquisador pôde identificar princípios subjacentes que norteou as dimensões explicativas frente às categorias, observando a relação hierárquica de complexidade exigida pelo método fenomenográfico (ARKELIND, 2005; MARTON e BOOTH, 1997), ou seja, as categorias descritivas foram hierarquizadas evoluindo da mais elementar à mais complexa, de forma que a anterior estivesse compreendida na categoria seguinte.

Em uma releitura final, os trechos agrupados foram lidos e relidos uma segunda vez, sob a visão de conjunto, consolidando as 3 principais categorias descritivas em ordem de complexidade e as respectivas dimensões que explicavam cada categoria. 
Conforme orientado por Bowden (2005), a influência do relacionamento entre o pesquisador e o fenômeno nos resultados deve ser reduzida a proporções mínimas, sendo apropriado ressaltar que o pesquisador procurou não fazer inferências na análise baseadas em suas concepções sobre o fenômeno. A análise foi centrada nas percepções descritas nos relatos organizadas como conjunto e observando os critérios de qualidade descritos por Marton e Both (1997) em seus estudos.

\subsection{1.}

\section{Limitações da abordagem de pesquisa}

A fenomenografia está sob o âmbito da pesquisa qualitativa e desenvolve pesquisas empíricas de caráter subjetivista. Vergara e Caldas (2005) ensinam que estudos de cunho subjetivista se caracterizam por amostras intencionais e coletadas de maneiras pouco estruturadas e baseiam suas análises em reflexões de natureza interpretativas, não podendo generalizar os resultados encontrados, tornando essas características fontes de questionamento aos racionalistas. Contudo, a abordagem de pesquisa utilizada, se apega a critérios que buscam garantir a validade e confiabilidade dos dados oriundos da pesquisa qualitativa, com algumas especificidades. Conforme Bowden (2005) ressalta, a análise deve se concentrar tão somente nas transcrições das entrevistas, o mapeamento da pesquisa deve minimizar os conceitos oriundos de relações entre o pesquisador e o fenômeno. Além disso, o pesquisador toma como base uma abordagem descontextualizada da transcrição, que, como Arkelind (2005) reflete, há algumas críticas a essa forma de análise visto que existe o receio de que o significado seja reduzido ao contexto específico da seleção do trecho, impactando a compreensão do real significado. Contudo, o pesquisador direcionou suas leituras e releituras das entrevistas integrais a buscar fragmentos demonstrassem ao máximo os significados presentes na entrevista.

Os fenomenógrafos assim como exposto por Marton e Both (1997) partem de uma perspectiva não dualista: não existem dois mundos, um interno e um externo; existe um único mundo onde todos vivenciam e experimentam. É válido ressaltar que a fenomenografia se diferencia da fenomenologia. Conforme reflete Marton (1981), o fenomenólogo analisa a experiência com objetivo de aprender sobre o fenômeno investigado, por sua vez, os fenomenográfos visam a aprender sobre as formas como sujeitos experimentam fenômeno. 


\section{4 \\ Resultados encontrados}

Neste capítulo serão apresentados e discutidos os resultados da pesquisa que originou um espaço de resultados (outcome space), no qual estão dispostas as categorias descritivas organizadas e caracterizadas com base na complexidade do conjunto de significados (pool of meanings) percebidos pelos entrevistados quando expostos ao problema de pesquisa.

O constructo do termo "accountability" utilizado na pesquisa foi apresentado aos envolvidos nas rotinas de controles internos e os relatos retornaram dimensões explicativas que elucidam a gradação e o envolvimento entre as categorias descritivas, em sua maioria, utilizando exemplos.

O capítulo está dividido em três seções. A primeira delas discorre sobre a empresa onde a pesquisa foi realizada. Esta contextualização se faz necessária em função da organização estar inserida em um mercado regulado, o que pode influenciar nas estruturas da organização e nos conhecimentos dos entrevistados. Na segunda seção são contextualizadas as categorias descritivas e as dimensões explicativas que compõem o espaço de resultados. Serão relatadas suas características e os princípios ativos subjacentes que compõe cada concepção, bem como serão apresentadas uma breve introdução das dimensões que explicam as categorias envolvidas. Ainda nesta seção, dividida em subseções, as categorias descritivas serão discorridas e discutidas em detalhes, utilizando a literatura adequada como orientação e os trechos dos relatos para corroborar as análises e discussões. Na terceira seção, o espaço de resultados é representado de maneira holística, a fim de apresentar o resultado do conjunto de significados acerca da percepção do fenômeno investigado na pesquisa.

É válido ressaltar que alguns termos são específicos das rotinas organizacionais e do ambiente do mercado no qual a organização está inserida, para tanto, determinados termos estarão definidos no Apêndice II deste relatório de pesquisa. Os termos são de conhecimento do autor deste estudo e não causaram danos à análise e conclusões relacionadas. 


\section{1.}

\section{A empresa}

A empresa em que o que o presente estudo foi realizado está inserida no mercado segurador. É relevante salientar tal característica, pois esse mercado é regulado e, desde 2009, estabeleceu formalmente a necessidade de procedimentos formais e estruturas organizacionais que contemplassem aspectos relativos a riscos, controles, bem como normatizações relacionadas a responsabilização. Desta forma, assim como o exposto na seção de seleção dos sujeitos, os entrevistados são denominados "agentes de controles internos" e foram expostos a conhecimentos relacionados a controles internos, bem como realizam rotinas organizacionais relacionadas ao tema.

Vale ressaltar que não foi permitida a citação do nome das empresas envolvidas nos relatos. Desta forma, trataremos a organização na qual os entrevistados estão inseridos por "empresa X" e de "matriz" a principal empresa do grupo, proprietária da "empresa X".

\section{2.}

\section{As categorias descritivas e as dimensões explicativas}

O presente estudo buscou investigar a compreensão da accountability nas rotinas de controles internos. Após os procedimentos de coleta, tratamento e análise de dados, foram identificadas dentro do conjunto de significados (pool of meanings), três categorias descritivas: 1) Respeitar os artefatos; 2) Qualificar as rotinas e 3) Proteger a organização. As categorias foram hierarquizadas de forma que haja uma evolução entre elas, ou seja, a primeira categoria está contida dentro da categoria seguinte. A figura 5 ilustra a disposição das categorias descritivas considerando a abrangência e complexidade que emergiram dos resultados. 


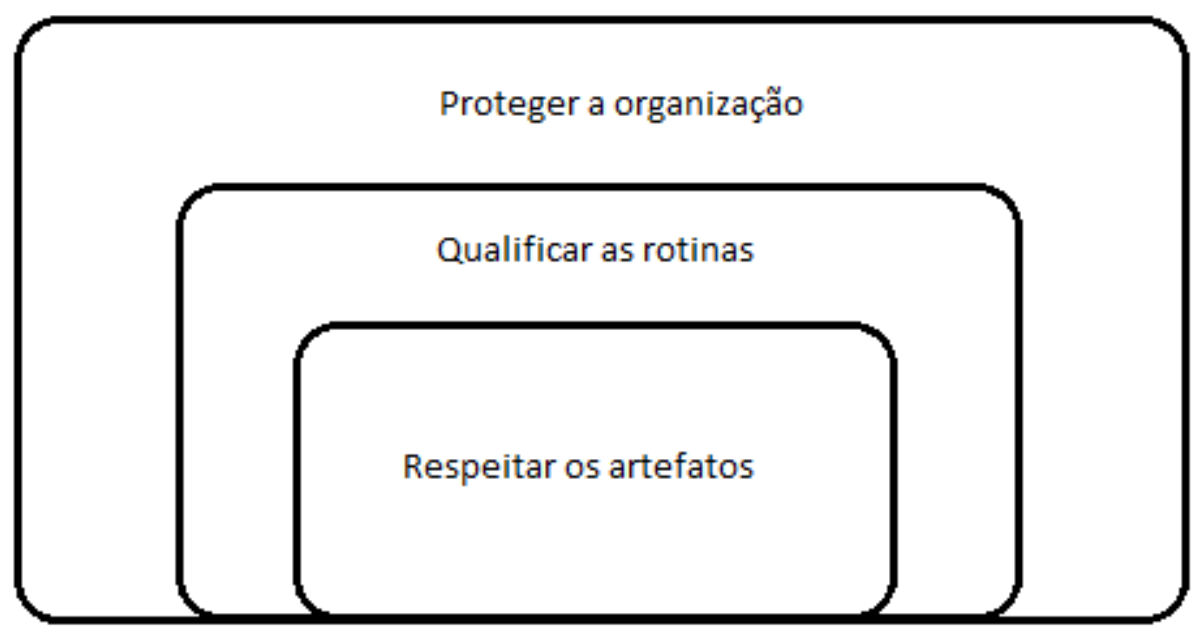

Figura 5: Hierarquia das categorias descritivas.

Fonte: Elaborado pela autora.

Respeitando a disposição do modelo hierárquico demonstrado na figura 5 , as dimensões identificadas que explicam as concepções, suas diferenças e relações a partir do relato dos entrevistados são: deferência à transparência; intensidade da interação dos aspectos; o senso de responsabilidade e o respeito ao controle.

Com base na análise das entrevistas foram identificados princípios subjacentes que norteiam as dimensões explicativas frente às concepções. Esses princípios subjacentes se concentram sobre as formas como a complexidade das concepções pode ser explicada pelas dimensões. Desta forma, foi construído o espaço de resultados (Seção 4.3).

A fim de subsidiar algumas considerações frente a conceitos apresentados por estruturas de governança corporativa na análise das entrevistas, é oportuno ressaltar os valores determinados pelo IBGC (2015), em seu código de boas práticas de governança corporativa, que envolvem pró-ativismo como elemento de desenvolver e disseminar as melhores práticas, diversidade, como elemento de diversidade de opiniões, independência como elemento de imparcialidade, soberania e preocupação com a imagem frente aos stakeholders, e coerência como elemento balizador entre os princípios de governança corporativa, que envolve transparência, equidade, accountability e a responsabilidade corporativa. Também é importante ressaltar, que esse documento traduz accountability como prestação de contas, o que cabe mencionar, as considerações de Pinho e Sacramento (2008) sobre a dificuldade que o termo tem para ser traduzido para o português, visto que, na visão desses autores, o termo carrega um conceito que envolve vários elementos, alguns percebidos pelos entrevistados no conjunto de significados identificados neste relatório de pesquisa. 
A "deferência à transparência" apresenta as nuances, desde a preocupação com a clareza nos artefatos normatizadores e nas respectivas falhas identificadas na prática, à preocupação em gerar confiança aos stakeholders. Essa categoria carrega o termo deferência no sentido de uma atitude de respeito a transparência. A visão de transparência exposta nos relatos pode ter uma ligação frente ao histórico que fortaleceu estabelecimento e a formalização das rotinas de controles internos. No ano de 2001, foram descobertas manipulações contábeis na empresa americana ENRON e entre outras grandes empresas de capital aberto. Esse fato, perpetuou um nível de desconfiança no mercado de capitais (BORGETH, 2005). Em vista dos escândalos relacionados ao tema na época, o governo americano inseriu uma série de medidas regulatórias, dentre elas foi sancionada a Lei Sarbanes-Oxley (SOX). A SOX serviu de base para várias regulamentações pelo mundo que objetivam o aprimoramento dos controles internos (IBGC, 2015). Segundo Borgeth (2005), o principal objetivo da lei foi estabelecer sanções que inibissem ações antiéticas e em dissonância com as boas práticas de governança corporativa por parte das empresas que atuam no mercado americano, bem como recuperar o nível de confiança das informações geradas pelas empresas. As medidas de confiabilidade estão envolvidas com transparência tendo em vista que a lei, além de estabelecer diversas divulgações de informações financeiras, também estabelece avaliações periódicas dos controles e procedimentos internos referente aos relatórios financeiros.

A "intensidade da interação dos aspectos" diz respeito a melhorias dos processos com base num movimento circular entre o aspecto ostensivo e o performativo. Conforme refletem Feldman e Pentland (2003), o relacionamento recursivo entre os aspectos ostensivos e performativos nas rotinas organizacionais, criando e recriando os aspectos ostensivos e performativos podem restringir ou permitir as perfomances.

O nível em que a recursividade é permitida, desde uma rotina fortemente estabelecida e com poucas chances de mudança, ao processo de melhoria e aperfeiçoamento das rotinas com base não apenas no aspecto ostensivo, mas no performativo, considerando as duas forças dos aspectos para estabelecer as melhorias dos processos caracterizam essa categoria. Os relatos dos entrevistados ilustram níveis que variam desde ações que permitiram pouca recursividade - em virtude de cumprir as normas com padronizações com pouca flexibilidade -, a citações de exemplos em que é possível visualizar interações entre os aspectos ostensivos, performativos e os artefatos envolvidos que 
buscam qualificar a rotina de controles internos, utilizando os conhecimentos dos atores e em alguns casos com o advento da verificação do valor.

O "senso de responsabilidade" envolve a visualização de variações da abrangência do estado do que é ser responsável. Configura-se aqui a percepção do entrevistado da accountability como algo em que ele tem participação. Os relatos expuseram percepções tanto de responsabilidade objetiva como subjetiva. A responsabilidade objetiva mais presente na categoria de respeito aos artefatos, mais direcionado ao não cumprimento dos normativos, contudo, também se apresente ao nível de valor com o receio de que a organização seja penalizada. Não obstante, a responsabilidade subjetiva também pode ser atribuída na categoria, posto que há relatos que apresentam uma cobrança interior que os próprios entrevistados fazem sobre si, conforme Trosa (2001) elucida. É válido ressaltar que, independentemente do tipo de responsabilidade identificada, a responsabilidade é um aspecto presente no conceito de accountability utilizado nesse estudo. Conforme observado na literatura apresentada neste relatório de pesquisa, o senso de responsabilidade, inclusive com atos punitivos por não cumprimentos ou desvios, são relevantes a este conceito, ainda que alguns autores como Trosa (2001), salientem que é importante que o fundamento vá além de ameaças e sanções.

O "respeito ao controle" está relacionado à mitigação dos riscos e preocupação com um ambiente de controle (COSO, 2013). Os movimentos são direcionados a realizar controles para garantir o cumprimento das normas, estabelecer e revisar controles para garantir a realização dos processos e ao direcionamento do controle para evitar a exposição da organização. Esses conceitos estão ligados a direcionamentos dados pela Governança Corporativa e o que esta estrutura considera como "boas práticas". Ainda que as boas práticas possam ser apresentadas como rotinas de conformidade (CHERMAN e ROCHAPINTO, 2016), alguns princípios relacionados, surgem nos relatos como objetos de valor, retornando como componentes presente na categoria descritiva mais complexa relacionada a proteger a organização.

Apesar de não ser o objeto deste estudo, considerando ainda, a perspectiva do respeito ao controle, cabe complementar a análise, o fato de que, em determinados relatos, alguns entrevistados chegam a confundir o conceito de controles internos como rotina e como área de controles internos. O fato pode representar uma forte presença da estrutura nas rotinas de controles internos da organização, demonstrando ser um agente com força substancial. Quando relacionado ao conceito de accountability, alguns entenderam que este conceito 
era a própria área de controles internos. A consideração se faz importante para identificar a proximidade entre accountability e as rotinas de controles internos. Contudo, o estudo da área de controles internos como estrutura organizacional e a accountability servem de agenda para próximos estudos desenvolvidos sobre 0 tema.

\subsection{1.}

\section{Respeitar os artefatos}

Com base nas entrevistas realizadas com os envolvidos nas rotinas de controles internos, a primeira categoria descritiva identificada foi "respeitar os artefatos". Essa categoria se caracteriza pela percepção principal dos entrevistados em entenderem a accountability, no contexto de controles internos, com o foco em cumprir as normas, sejam elas estabelecidas pelos órgãos reguladores ou pela organização. O COSO (2013) define controles internos como um processo conduzido pela governança, pela administração e profissionais da organização, com o intuito de tentar possibilitar a realização de objetivos relacionados a eficácia e eficiências das operações; divulgação podendo englobar conceitos confiabilidade; transparência; oportunidade e conformidade com leis e regulamentos aplicáveis.um processo. Nesta categoria, o artefato se apresenta como formalizador da rotina organizacional ou como determinante da vontade do órgão regulador. Os processos e a visão de accountability estão ligados a uma rotina de conformidade (CHERMAN e ROCHA-PINTO, 2016), com pouca disponibilidade para mudança e de caráter fortemente ostensivo (FELDMAN e PENTLAND 2003). Os atores por vezes questionam as regras estabelecidas no artefato, mas as normas surgem com uma força expansiva abrandando os questionamentos por meio de uma dominação política. (FRIEL e LARTY, 2013).

"Se a corporação define como correto, deve ser tomado como tal. E eu tinha grande dificuldade quando tinha a interpelação do porquê eu fazia daquela forma e ter controles internos para dizer: "Faço assim porque é assim que está escrito na instrução normativa. É assim que é feito para que não haja risco. É assim que é feito para que não haja um erro". Foi ótimo. Eu me senti mais segura até para poder dizer, defender a forma com que eu trabalhava." (Entrevista 1)

Em linha com o exposto pelos entrevistados, pode-se verificar que a rotina de controles internos nesse nível é vista predominantemente para o cumprimento de um normativo do órgão regulador ou interno. Contudo, as experiências dos entrevistados demonstram já nesta concepção a visão de rotina organizacional e não individual (JARDIM, 2017), que envolve várias áreas, a 
interdependência entre elas e suas respectivas ações (PENTLAND e FELDMAN, 2005).

"A preocupação da área, isso inclusive envolveu o controles internos, na questão de uma nova circular (...), que exigia que a companhia deixasse de ter uma nota técnica atuarial e passasse a ter uma nota técnica de produto. (...) a gente acabou movendo grande parte da companhia, inclusive superintendência pra que todo essa... essa legislação fosse cumprida e ela foi cumprida no último dia, e a gente conseguiu implantar o produto e protocolar a nota técnica dentro do prazo esperado. (...) o que favoreceu, além da responsabilidade das áreas envolvidas, acho que a urgência e o comprometimento de todos. (...) inclusive a aproximação das áreas, porque é uma área que até então a gente não tinha muito contato. Então a gente passou a ter o contato, até pelo novo... pela nova forma da companhia também de ser um jurídico corporativo e não mais o jurídico físico, aqui na... aqui na empresa X. Então eu acho que o que mais favoreceu foi a responsabilidade." (Entrevista 5)

Conforme elucidado anteriormente, este estudo foi realizado em uma empresa do mercado segurador. Dentro dessa abordagem, isso significa um ambiente regulado, caracterizado por uma concentração forte em artefatos relacionados a regras, procedimentos, normativos e possíveis penalidades em caso de descumprimento de padrões estabelecidos. Segundo Pentland e Feldman (2005), em um ambiente com um forte comando e controle, os procedimentos operacionais padronizados (SOP - Standard Operating Producers) são a ordem. Desta forma, nessa categoria, os exemplos relacionados apontam a força das legislações nos procedimentos de controle em que, a todo momento o ambiente de controle (COSO, 2013) é fortificado para o cumprimento de normativos internos e externos.

“...existiu já casos de a gente pegar, que o número que tava lá não era condizente que tava aqui. Os números geralmente são muito parecidos $e$, nesse caso, a gente viu que o número realmente não tava coerente e a gente retornou o assunto pra matriz e eles verificaram que realmente houve um erro na hora de fazer a planilha e que o valor que eles acabaram pagando pro corretor foi indevido (...) Hoje, quando a gente faz a parte de cadastro, eu faço todas as verificações de Receita Federal e de Susep aqui. Essa semana mesmo eu peguei dois casos de CNPJs baixados na Susep e que a matriz liberou o cadastro desses corretores. Então, eu retorno pra matriz falando "olha, a empresa $X$ não liberou esses CNPJs porque estão baixados na Receita e eu não posso permitir que esse corretor emita na empresa X" e a gente orienta que lá na matriz também seja feita a inativação desses corretores. (Entrevista 6)

“...a gente recebe um oficio de alguma fiscalização e é delegado pra gente, pra gente responder, porque deve ser pertinente à minha área. E quando a gente tá respondendo essa informação, sempre acontece o departamento de controles internos, além de querer acompanhar, ele se coloca à disposição pra poder ajudar, isso não é uma coisa que fica de boca pra fora, na verdade é uma coisa que acontece mesmo, as pessoas se acompanham, participam e vão sempre atrás do que precisa ser feito pra responder, pra que tudo seja feito no tempo adequado e corretamente." (Entrevista 16) 
Seguindo a dimensão explicativa relacionada ao senso de responsabilidade, os exemplos listados reforçam a questão da responsabilidade em estar cumprindo exigências regulatórias e normas internas. Por vezes os entrevistados tratam tanto da responsabilidade objetiva acarretando em possíveis punições pelo descumprimento de diretrizes (MOSHER, 1990) bem como da responsabilidade subjetiva, menos relacionada a sanções, uma ideia mais focada na cobrança que um sujeito faz sobre si. (TROSA, 2001; PINHO e SACRAMENTO, 2008).

"Olha, já tivemos um exemplo na empresa no passado que era uma determinada obrigação de você comunicar negócios que você aceitava e que você trabalhava, acima de um determinado valor em risco, por exemplo, acima de um milhão. (...) E alguns casos, por não estarem $100 \%$ mapeados no controle que você fazia, aquilo deixou de ser informado e sendo identificado, e tendo que ser informado posteriormente. Então, os envolvidos responsáveis por aquilo, responderam por aquela falha, perante ao órgão, o órgão entendeu e pediu aquela comunicação. Então aquilo foi feito e dali para frente foi colocado o parâmetro interno para que casos semelhantes não ocorressem mais. "(Entrevista 9)

"Eu acho que justamente essa responsabilização né, das áreas com apoio de controles internos, pra gente garantir que tudo esteja funcionando corretamente, que a gente não... não esteja andando fora da norma, que as práticas que a gente está adotando no nosso dia-a-dia, nas tarefas, nas atividades né, estejam adequadas e não infrinjam nenhum... nenhuma questão ética, nenhuma questão de norma né, eu acho que ter controle disso também né, então a gente tem que ter também o controle das atividades adequadamente pra gente saber o que que está acontecendo na área, se está corretamente, ter manuais das coisas..." (Entrevista 14)

O papel de determinados artefatos como símbolo de transparência, tanto dos dados que estão expostos, aos relatórios que apresentam as falhas e as correções estabelecidas conduzem nuances das rotinas de controles internos na organização focada em atender normativos externos reguladores.

“...o próprio relatório da auditoria, ele é uma coisa que faz a transparência, ou seja, ele indica onde você estava errado, indica qual é a regulação da empresa, ou seja, o regulamento, a normativa que você está fora dela, indica aquilo que pode ocorrer, que você pode ter penalidades ou pelo órgão regulador, que o nosso caso é a Susep, indique e te dá um prazo de acerto. Então acho que a aplicação está nesse processo, entendeu?" (Entrevista 7) 
Apesar de haver uma interação entre o aspecto ostensivo e performativo, os relatos apontam pouca retroalimentação entre eles. O movimento recursivo, apesar de acontecer, não é recorrente, pois há uma relação de poder que pende muito mais para o órgão regulador e as determinações da organização, para as regras e procedimentos estabelecidos e pouco se vê nessa concepção interações que fomentem a melhoria de processos. O aspecto performativo está reduzido a cumprir as obrigações e evitar sanções.

“...hoje nós temos um novo sistema de emissão e uma preocupação muito grande que a gente teve, foi justamente com essa questão do PEP, pessoa politicamente exposta, então, um ponto muito crucial em todas as discussões que a gente teve com a empresa terceirizada que está implantando esse novo sistema, é de que a gente precisa automaticamente ter já uma tratativa especifica pra pessoas politicamente expostas, (...). Então é um exemplo muito clássico de independente de como a companhia mude o seu sistema de trabalho de emissão, já tá muito claro, tá muito enraizado nas equipes que tem que se ter um cuidado muito grande na questão de PEP." (Entrevista 12)

Desta forma, o que pode ser vislumbrando é uma categoria descritiva que concentra relações de transparência, ajustes nos processos, senso de responsabilidade e respeito ao controle com uma construção instrumental; rotinas centradas no poder dos artefatos relacionados à conformidade, ao cumprimento dos normativos, não necessariamente em uma troca de conhecimento que evolua fundamentalmente para a melhoria dos processos e no estabelecimento de valor. Apesar dos atores envolvidos terem suas próprias interpretações da rotina (FELDMAN e PENTLAND 2003), o artefato não permite uma margem significativa de manobra ao envolvido e é visto como obrigação ou com um reduzido espaço para questionamentos.

\subsection{2.}

\section{Qualificar as rotinas}

Essa concepção apresentou os relatos relacionados à compreensão de accountability direcionada a assegurar e qualificar as rotinas. Também é apropriado salientar que nesta categoria descritiva é perceptível a estrutura interna da rotina (PENTLAND e FELDMAN, 2005). As experiências dos entrevistados trazem à tona por diversas vezes, as possibilidades a serem consideradas: performances, os aspectos ostensivos e os artefatos relacionados (PENTLAND e FELDMAN, 2005). Ainda segundo considerações dos autores, também são perceptíveis nos relatos, as relações entre os aspectos ostensivos e performativos; a performance e artefatos e o ostensivo e os artefatos. 
Diferente de uma visão de rotina como "inflexível" e "morta", meramente codificada em artefatos conforme ensina Michael Cohen (2007), essa concepção sugere uma progressão dos artefatos focada em melhorar os processos. D'Adderio (2008) relembra que é fundamental distinguir os procedimentos operacionais padronizados e as rotinas para que se compreenda que as rotinas vão além dos artefatos e que os artefatos são uma representação parcial da rotina, e não uma representação efetiva do aspecto ostensivo. Os relatos apontam uma preocupação com a rotina e sua melhoria é menos latente. $\mathrm{O}$ respeito à transparência com relação à exposição das falhas identificadas remete a identificação de oportunidades de melhoria no processo, nos artefatos envolvidos, na qualidade da rotina. Ainda sobre os relatos, eles sugerem uma transgressão da visão puramente direcionada em atender ou implementar artefatos a evoluir processos e artefatos.

“...uma coisa que é muito latente é a transparência né? A gente tem... os testes de controle nos traz grandes oportunidades de melhorar, porque nós, no caso eu como papel de gestor, eu não posso encobrir falhas técnicas né, na verdade o meu grande interesse é expor mesmo né, falhas técnicas, falhas de processos, riscos pra que a gente justamente possa evitar com que essas coisas acontecem ou mitigar né, mitigar risco, mitigar possibilidade de problema. Então assim, os testes de controle né, eu acho que é uma das primeiras frentes que nos ajudam a poder melhorar o nosso processo, porque se não for transparente, se não tiver esses testes a gente não tem a oportunidade de melhorar fluxo, melhorar procedimento, melhorar qualidade. Então é algo que tá ligado diretamente a qualidade do processo né?" (Entrevista 2)

É tempestivo considerar que, conforme Pentland e Feldman (2005) definem, o aspecto ostensivo de uma rotina é uma visão abstrata padrão da rotina, é o que os envolvidos usam para se orientar ou explicar performances específicas da rotina. Ainda sob a força do aspecto ostensivo e dos artefatos regulatórios, podem-se visualizar construções nos sistemas da organização para adequação a esses normativos. Utilizando a visão de D'Adderio (2003), verificase a rotina trabalhada em uma transposição de conhecimentos dos analistas, das áreas envolvidas, da legislação, da aprendizagem e de um conhecimento em um artefato, podendo ser fluxos, sistemas, ou artefatos que envolvidos na rotina. A responsabilidade envolve cumprir uma legislação, mas envolvendo a equipe no sentido de estar fixado no dia-a-dia, na responsabilidade e engajamento no atendimento e implementação das legislações e normas, a evitar novos erros, a tornar o processo mais maduro no sentido de que a rotina está além da representação das regras e procedimentos em artefatos. 
“...Eu acho que todos... todos têm que estar não envolvidos com accountability, mas sim comprometidos com accountability, entendeu? Aquele dilema do "Por que da galinha"... É porque é assim, a galinha, ela está sempre... a galinha pra alimentar o homem, ela é envolvida no processo, ela bota o ovo e vai embora e depois ó, o que você faz ali ó... o problema é seu. Agora o porco não, o porco, ele é comprometido, o porco, ele morre pra te alimentar, então, ele vai até o fim para aquilo dar certo, entendeu? Então é mais ou menos isso. Então a gente tem que deixar assim, as pessoas têm que ser menos galinhas e mais porcos dentro deste cenário. Entendeu?" (Entrevista 10)

Como a categoria se apresenta em um nível no qual há uma maior recursividade entre os aspectos ostensivos e performativos, as experiências dos profissionais envolvidos com as rotinas de controles internos sugerem aproximar tanto a questão das exigências dos artefatos, quanto trabalho com a rotina para obter a melhoria de todo o processo com foco na fluidez da rotina. O ponto é evoluir nas discussões, considerar o conhecimento das áreas envolvidas com a legislação e a rotina, com o intuito de não se conformar com a rotina estática; pensar em amadurecer o processo. Dentro desta temática, é oportuno trazer à tona a reflexão de D'Adderio (2011) em relação ao artefato como elemento central das rotinas, levantando a discussão da coevolução mediante o envolvimento em lutas performativas. As entrevistas revelam um desconforto com o imposto sem discussão. Contudo, diferentemente da categoria descritiva "respeitar os artefatos", sugerem que a saída para qualidade do processo é a discussão, o envolvimento entre os atores da rotina, o questionamento e a retroalimentação de ambos os aspectos. As situações expostas pelos relatos envolveram tanto processos internos, com a preocupação não só com a legislação, mas com o cliente, bem como a discussões com o próprio órgão regulador, culminando numa compreensão do órgão frente a necessidade apresentada pelo mercado, modificando o entendimento do órgão. Nesse momento, pode-se notar uma evolução nas inter-relações entre os aspectos ostensivo, performativo e os artefatos envolvidos. Com base na interação entre eles e nas percepções dos atores envolvidos nas rotinas, os participantes da rotina buscaram a qualidade do processo.

"A gente tinha um grande problema que era a questão da circular 445, primeiro com relação à interpretação, né? A gente tinha uma interpretação, controles internos tinha outra interpretação, a nossa área lá da matriz tinha outra interpretação. E em todas essas cabeças pensantes também tinha um apetite ao risco ou um entendimento de que aquilo seria um grande ou pequeno risco, né? (...)A gente se uniu num trabalho. Primeiro, pra dissecar a circular, pra alinhar entendimentos (...)Levei o assunto pra matriz em São Paulo (...) Lá era mínimo, aqui era máximo. E a gente pra dar fluidez precisava ter uma coluna do meio aí, né? (...) a gente ficou um pouco com o espírito inconformado. (...) Criamos algo que mitiga a possibilidade de não cumprimento da circular, né? Tendo a questão 
do controle, até da questão da garantia que os processos vão funcionar normalmente aqui, que é uma grande preocupação. A gente não pode também preterir o controle, só não ocorrência do risco e não olhar pro cliente. A gente tem que... acho que a grande arte é juntar esses dois pontos, né? E foi um trabalho feito a quatro mãos muito bem acolhido pelo controle interno e amadurecimento também dos nossos processos. " (Entrevista 4)

"No meu setor... é a questão da responsabilização eu vejo mais, assim o foco, eu acabei até de falar agora, da cobertura exclusiva de RCF, a gente procurou tomar esse cuidado pra não perder os prazos (...)Então assim, eu procurei, ao menos na minha área, ter essa responsabilidade no sentido de minimizar umas outras questões que poderia piorar tudo, entendeu? Mas em conjunto com o controle interno, em conjunto com o jurídico na época, a gente conseguiu ter todo o contexto, ter todo o embasamento que de fato a gente poderia sim, (...) e ainda assim no prazo que eles limitaram, sobre realmente ter que fazer um novo processo Susep, a gente procurou analisar e teve essas reuniões que eu havia falado e, que foi tranquilo, realmente a Susep enxergou a necessidade do mercado segurador, que não tinha a necessidade de fazer um novo processo, (...) e a gente pôde fazer outras melhorias com isso também..." (Entrevista 17)

“... a minha área foi pontuada como... como um processo que estava em falha de controle de contratos, a parceria, ela existiu quando vem sugestões de como eu poderia melhorar o meu processo. Então, explicando o processo, como é que eu posso melhorar ou, quando a gente constrói uma matriz de risco da área, a troca que a gente tem de informação, a troca que a gente tem de conhecimento, como é que a gente pode usar essa troca pra melhorar um procedimento na minha área ou melhorar um controle na minha área. Não é dizer que os controles internos que vai controlar, mas é a troca de conhecimento e a ajuda que se tem como apoio pra caminhar pra um controle melhor, pra atingir um resultado melhor dentro da área." (Entrevista 8)

$\mathrm{Na}$ mesma linha, o respeito ao controle é fortificado pela intenção de mitigar riscos, assegurando a rotina ou verificando alterações que caminhem para seu amadurecimento. Os questionamentos e trocas entre as áreas envolvidas na rotina de controle interno são direcionados em verificar se o controle ainda faz sentido, se há possibilidade de melhorias e se a rotina está desalinhada com o proposto, demonstrando uma maior intensidade na interação dos aspectos. Cabe aqui retomar a intenção de um ambiente com forte controle. Contudo, os relatos retornam possibilidades de repensar o processo em busca de uma melhoria de performance.

“...por exemplo, (...) a gente está fazendo um trabalho das matrizes de riscos de TI, (...) Você tem lá as duas áreas: controle internos e gestão de riscos, você tem uma série de riscos que foram levantados pela área de gestão de risco e você traz os responsáveis dessas áreas, ou seja, as pessoas que estão assumindo a responsabilidade para dizer quais são os controles que ele implementa. Obviamente aí tem uma discussão para ver se o controle é efetivo, se não é(...). Após desse trabalho todos os controles que a área diz que foram, que são eficientes, que são implementados, controles internos faz um check. (...), então ela vê se aquele controle que eu disse que eu possuo, ele realmente existe e se está sendo seguido. Obviamente os controles que não são eficazes, a gente traça um 
plano de ação em conjunto e o controles internos vai lá e nos cobram as devidas ações sobre os planos." (Entrevista 10)

"A gente tinha um problema na questão da monitoria, né? A proposta às vezes ela era liberada para emissão e a gente não tinha um relatório que dizia que aquela proposta estava parada para que não passasse dos 30 dias da emissão. Então aí depois de um controle interno, foi feito um relatório de monitoria, que a partir do vigésimo dia de transmissão que uma proposta é liberada pra emissão e ela está parada no sistema, sai aquele relatório e a gente faz um acompanhamento diário. A gente entra pra ver se ela está parada porque ela está aguardando um crédito e ela está dentro do prazo mesmo ou por alguma falha humana ela ficou parada ou até erro sistêmico. (Entrevista 13)

“...tínhamos um controle de qualidade em que tinha que bater prêmios, alterações, é... alterações na proposta, na emissão. (...) Foram tantas mudanças que nós tivemos junto ao controle de qualidade que esse relatório ficou perdido, não foi feito mais, a gente estava fazendo um controle de qualidade técnico, do técnico e não o controle de qualidade em relação à documentação que chegava transmitida e o que saía, né? E foi necessário entrar o controle interno pedindo... é aquilo que eu falo, controles internos não está aqui pra te julgar que está errado, é pra te ajudar a desenvolver... desenvolver controles para dar certo, darem certos né. Então foi aí que a gente viu que a gente estava errado. Estava faltando esse relatório pra realmente bater. (...) não tínhamos e agora já está desenhado e pronto pra sair o primeiro relatório, e a gente se perdeu nisso e realmente foi pego de surpresa..."(Entrevista 18)

“(...) nós realizamos um teste de controle e foi apurado que algumas cartas negativas, recusas não estavam sendo encaminhadas para o cliente. E a partir desse momento foi criado um teste de controle, onde a gente acompanhou, fez algumas melhorias sistêmicas que acabou culminando na qualidade da entrega da informação ao cliente. (...) em algum momento eu deixei de comunicar ele sobre uma futura negativa deixando uma fragilidade pra nossa companhia. E, a partir daí, foram desenvolvidas algumas regras sistêmicas onde garantia que a carta negativa, o processo só seria encerrado após o envio da carta recusa." (Entrevista 19)

Ainda sobre os relatos listados acima, é perceptível que a troca de conhecimento entre as áreas, sobretudo, controles internos e a área que executa a rotina é positiva aos entrevistados. Desta forma, é oportuno acrescentar que a área de controles internos aparece como um dos atores envolvidos nas rotinas relacionadas, mesmo que executada pela área de negócio e os relatos são balizados pela busca em garantir a execução dos processos e a qualidade das atividades executadas. 
Em suma, as experiências narradas pelos envolvidos nas rotinas de controles internos nesta concepção fazem várias correlações entre artefatos, aspectos ostensivos e performativos (PENTLAND e FELDMAN, 2005). A interrelação entre eles, demonstra um olhar direcionado à melhoria dos processos. $A$ complexidade da categoria descritiva evolui na direção do amadurecimento do processo, considerando a transparência, o senso de responsabilidade, um nível maior na interação dos aspectos ostensivos e performativos e o controle voltado não somente para o cumprimento da legislação, mas para uma performance sustentável nas rotinas de controle interno, uma busca para fluidificar os processos considerando a rotina com uma visão de conjunto complexo de atividades (FELDMAN e PENTLAND, 2003).

Analisando esse movimento entre o ostensivo e o performativo nas rotinas de controles internos, os relatos ainda sugerem oportunidades para que os envolvidos produzam variações da rotina e possam escolher as variações (FELDMAN e PENTLAND, 2003), utilizando-as para o que os participantes entendam como melhoria nos processos.

\subsection{3. \\ Proteger a organização}

O nível mais complexo do espaço de resultados encontrado, traz a percepção dos entrevistados da accountability frente às rotinas de controles internos como valor. A visão do IBGC (2015) discorre cidadania corporativa em vista da empresa com atuação responsável, considerando não somente os artefatos legais e regulatórios, mas considerando os stakeholders nas suas atividades bem como considerar em suas ações organizacionais os efeitos que causam na sociedade. Ainda sobre a visão do IBGC (2015) em seu código das melhores práticas de governança, ele lista como indispensável ao ambiente em linha com a governança a ética, honestidade, integridade, responsabilidade, independência, visão de longo prazo e uma preocupação genuína com os impactos das atividades organizacionais para um sucesso perene das organizações. Utilizando a definição do COSO (2013) de controle interno como um processo com o intuito de salvaguardar a realização de objetivos relacionados a eficácia e eficiência das operações; divulgação de informações podendo englobar conceitos confiabilidade; transparência; oportunidade e conformidade com leis e regulamentos aplicáveis, os relatos trazem a luz a compreensão de accountability como um valor na organização. Nesta categoria descritiva, as dimensões explicativas aparecem como um resguardo a 
organização. Os relatos apresentam a transparência como a exposição de dados e riscos identificados com clareza, o que remete a uma confiabilidade às partes interessadas, bem como ao comprometimento da organização com controles internos e compliance e a relação entre as ações realizadas e os objetivos da estabelecidos pela organização.

"Nós temos uma rotina que é a base de perdas operacionais né? Eu acho que isso exemplifica bastante esse conceito, porque basicamente eu tenho que (reportar) a área de controle interno quando algum processo meu gera um prejuízo pra companhia, pra minha área. E desse relato né, desse relato a gente vai tá contribuindo de uma forma transparente, ela precisa ser justificada e ela aconteceu porque alguma coisa deixou de ser cumprida né? Então essa rotina mensal que nós temos eu acho que configura bem esse conceito." (Entrevista 2)

“...existe a reunião pra definir quais são os itens de tarifa. O que que é isso? É o que o mercado, o que o mercado tá trabalhando e o que que a empresa define que será o melhor caminho a ser tomado. Isso é definido numa reunião de superintendência e gerência. (...) Aí depois, existe uma reunião de dúvidas, (...) nessa reunião onde todas as partes vão tomar conhecimento daquela ata, daquele item e quais são os impactos nas áreas e na outra empresa(...) Aí tem a área... a reunião de aceite, onde aí sim, todas as áreas trazem o que pode ou não e qual a justificava pra não acontecer aquela... aquela determinada implantação. Aí nessa reunião de aceite que é definido todas as situações a serem tomadas. (Entrevista 3)

“... tem todo o sentido de aplicação porque é justamente o que o controles internos faz. Ele tem que ter o controle, ele tem que verificar informações com transparência, você não pode gerar um tipo de informação que seja incorreta, você pode ter uma penalidade por estar registrando qualquer informação ou qualquer registro ou contábil, que seja, ou de garantias que seja da empresa, errado. Então você tem que ter esse tipo de aplicação, você tem que ter um controle específico, um controle que gere transparência, um controle que seja, vamos dizer assim, que tenha um entendimento das normativas ou da legislação vigente, né, e você tem um conceito que você pode aplicar justamente pra que isso siga uma linha, vamos dizer, coerente e assertiva, né?" (Entrevista 7)

(...) Hoje no mundo que a gente vive, até mesmo pra que a empresa gere transparência pra fora, até mesmo porque gerando essa transparência existe a confiabilidade de mercado, existe a confiabilidade que a empresa é uma empresa sólida, que é uma empresa que não tem risco, né, ou que o risco seja mínimo. Então esse tipo de informação hoje é crucial, eu acho que pra empresa hoje num mercado que a gente tem competitivo, onde as pessoas estão procurando empresas que possa confiar, que possa ter garantias. A gente cuida de serviços que são serviços de garantia de bens dos segurados. Então a empresa tem que ter uma garantia, ela tem que ter uma transparência, ela tem que ter, vamos dizer assim, regulações que gerem pra fora daqui, segurança." (Entrevista 7) 


\begin{abstract}
"Na companhia anterior onde trabalhei, a gerência da sucursal manipulava os resultados de performance. Só que manipulava de uma forma muito sutil. Então a companhia levou bastante tempo pra entender como aquilo acontecia, porque os resultados da sucursal como um todo eram bastante bons. (...) Só que depois de uma investigação assim um pouquinho grande, da qual inclusive a área que partici... que eu trabalhava participou, foi que nós começamos a entender mal, muito mal comparando, era como se fosse uma espécie Lava Jato da época. Então mediante ao input de dados descasados com a realidade, o resultado final aparece bonito na foto, mas não é isso que acontece na realidade. E aí quando isso foi devidamente comprovado, aí a decisão foi tomada e foi uma quantidade grande de pessoas, inclusive, que foi mandada embora. Por justa causa, inclusive." (Entrevista 11)
\end{abstract}

Vale ressaltar que nessa categoria descritiva é possível ver que, na percepção dos entrevistados, a transparência aparece como valor, trazendo semelhança ao exposto por Koppell (2005) que caracteriza a transparência como o "valor literal" da accountability. Para o autor, a transparência além de ser um instrumento para avaliar o desempenho organizacional, fortalece que informações verdadeiras estejam à disposição dos acionistas, fornecedores, membros da organização, entre outros atores organizacionais e, uma organização "accountable" não pode omitir seus erros. A percepção dos relatos envolve a transparência e os controles estabelecidos a um caráter de estabelecer ou assegurar uma confiança para o mercado.

Sob a ótica da rotina, o nível de interação entre os aspectos ostensivos e performativos reúne uma preocupação com o conhecimento frente ao processo, em rever os processos, mesmo quando automatizados, revalidá-los tendo em vista que envolve a imagem da organização como elemento reputacional. Neste âmbito, há uma preocupação em revisar processos e rotinas, monitorar os processos organizacionais com intenções voltadas a longo prazo e com preocupação com o impacto que possíveis erros possam atingir ao nome da organização.

"Eu acho que o conhecimento do processo, ele é fundamental pra que a gente consiga verificar... não é uma conferência, mas eu acho que é uma homologação do processo. Então, hoje existe o processo, alguém fez o processo correr, mas a gente, quando chega aqui o processo, na hora que envolve o nome da empresa $X$, a gente teve o cuidado de revalidar essas informações, principalmente nos órgãos competentes que a gente tem acesso, pra verificar se realmente, de fato, (...) não deixar que seja só um processo automatizado e se perder ao passar dos tempos. Eu acho que revisitar o processo é importante, os conceitos do que aquilo pode causar se a gente permitir que isso continue né, o erro vá adiante. Eu acho que foi isso que gerou a identificação desses problemas e acho que isso foi importante." (Entrevista 6) 
Em linha com o conceito de accountability apresentado por Pinho e Sacramento (2008), os entrevistados demonstram uma consciência da sua responsabilidade e o seu impacto para organização, de forma que o profissional envolvido na rotina de controle interno se preocupa em preservar a organização no que tange a exposição da empresa, a sua imagem. Essa categoria pode sugerir uma conjunção quanto aos valores listados pelo IBGC (2015) e outras estruturas como o COSO (2013) que apresentam uma preocupação direta com a imagem da empresa. Contudo, os relatos parecem transpor uma visão que relaciona a imagem à valoração da organização frente ao mercado de ações e expõe algo mais subjetivo, como a confiabilidade, ao impacto dos envolvidos na rotina sobre a organização.

\begin{abstract}
“...quando eu tive contato com controles internos, a primeira vez, como agente, na elaboração da matriz de risco e tudo mais, foi quando eu tive noção de como era abrangente, de como o universo era maior, né? A gente tira o nosso olhar ali do micro e coloca o nosso olhar mais no macro, e a gente passa a ter uma outra visão, né, que é a visão de responsabilidade, não só do seu trabalho, (...) mas também a sua responsabilidade num todo, né? (...) E pensando no depois assim, conseguindo mitigar o risco, né, saber aonde que, dentro do meu trabalho, dentro da minha área, eu posso melhorar uma atividade, aonde aquela atividade pode me apresentar um risco, né, de colocar uma informação errada ou de deixar de passar uma informação, sempre no intuito de estar melhorando os processos dentro da minha área e mitigando o risco pra que não haja um problema futuro (...) Se eu estou passando uma informação confiável, se eu não estiver, o que que aquilo pode prejudicar o desenvolvimento da outra área. Então é a minha responsabilidade naquilo que eu faço, daquilo que eu mando, né, de que forma que eu mando pra também ser cuidadosa com o que o mercado vai receber, né, pra não expor também a minha empresa." (Entrevista 15)
\end{abstract}

“...esse conceito de responsabilização, eu acho que em uma boa administração, ele não deve permear não só os controles internos, né, tem que permear a própria área, né, porque é isso, todas as lideranças têm uma responsabilidade objetiva e subjetiva sobre as suas atribuições e suas decisões. Então, eu acho que o controles internos, ele como parceiro do negócio, ele tem que nos ajudar a internalizar melhor esse conceito, né? E, de fato, que isso possa inclusive ser repassado para os demais da área porque é isso, né, as decisões que a gente toma no nosso dia a dia impacta diretamente o negócio." (Entrevista 20)

Nesse sentido, é válido retomar a preocupação de Campos (1990) quanto a sua preocupação sobre uma cultura de accountability no Brasil frente a um cenário político pós-ditadura. Não menos relevante, essa categoria descritiva reforça que, observar valor na percepção de accountability pelos envolvidos nas rotinas de controles internos pode demonstrar, não um estabelecimento de uma cultura de accountability, mas uma proximidade maior do conceito. Ainda que, em sua totalidade, os entrevistados não reconheçam a palavra em sua nomenclatura inglesa, o conceito não demonstra distância da percepção dos 
envolvidos. Os relatos retornam um processo de amadurecimento do conceito culminando na percepção de valoração. Apesar de existir uma concentração em rotinas relacionadas a processos operacionais padrão (POP) em virtude de um forte caráter ostensivo, é possível verificar melhorias em questionamentos a rotinas, artefatos e no que é melhor para organização não apenas no que tange ao compliance, mas a responsabilidade de cada agente que participa dos processos, em uma visão macro da organização; em uma visão que engloba impactos internos e externos. 
4.3.

\section{O espaço de resultados}

\begin{tabular}{|c|c|c|c|c|c|c|}
\hline \multirow[b]{2}{*}{$\begin{array}{l}\text { Categorias } \\
\text { descritivas }\end{array}$} & \multirow[b]{2}{*}{$\begin{array}{l}\text { Princípio ativo } \\
\text { subjacente }\end{array}$} & \multicolumn{5}{|c|}{ Dimensões explicativas } \\
\hline & & Deferência à transparência & $\begin{array}{l}\text { Intensidade da } \\
\text { interação dos } \\
\text { aspectos }\end{array}$ & $\begin{array}{l}\text { Senso de } \\
\text { responsabilidade }\end{array}$ & Respeito ao controle & Entrevistas \\
\hline $\begin{array}{l}\text { Respeitar } \\
\text { os artefatos }\end{array}$ & $\begin{array}{l}\text { Cumprir as normas, } \\
\text { sejam do órgão } \\
\text { regulador ou } \\
\text { internas }\end{array}$ & $\begin{array}{l}\text { Clareza nos procedimentos } \\
\text { e exigências a serem } \\
\text { cumpridos bem como nas } \\
\text { respectivas falhas } \\
\text { identificadas }\end{array}$ & $\begin{array}{l}\text { Avaliação e } \\
\text { adequação o } \\
\text { processo garantindo } \\
\text { que a regra seja } \\
\text { seguida }\end{array}$ & $\begin{array}{l}\text { Responsabilidade no } \\
\text { atendimento e } \\
\text { implementação das } \\
\text { legislações e normas }\end{array}$ & $\begin{array}{l}\text { Realizar controles para } \\
\text { garantir o cumprimento } \\
\text { das normas }\end{array}$ & 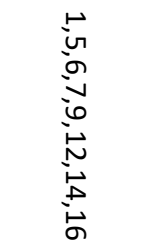 \\
\hline $\begin{array}{l}\text { Qualificar } \\
\text { as rotinas }\end{array}$ & $\begin{array}{l}\text { Garantir e promover } \\
\text { a qualidade das } \\
\text { rotinas }\end{array}$ & $\begin{array}{l}\text { Clareza nas falhas } \\
\text { identificadas para } \\
\text { melhorar procedimentos e } \\
\text { qualidade }\end{array}$ & $\begin{array}{l}\text { Garantia e } \\
\text { amadurecimento dos } \\
\text { processos }\end{array}$ & $\begin{array}{l}\text { Responsabilidade em } \\
\text { realizar as rotinas } \\
\text { conforme estabelecidas }\end{array}$ & $\begin{array}{l}\text { Estabelecer e revisar } \\
\text { controles para garantir a } \\
\text { realização dos processos }\end{array}$ & 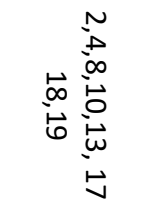 \\
\hline $\begin{array}{l}\text { Proteger a } \\
\text { organização }\end{array}$ & $\begin{array}{l}\text { Preservar a } \\
\text { organização no que } \\
\text { tange a sua imagem } \\
\text { e aos seus objetivos }\end{array}$ & $\begin{array}{l}\text { Comprometimento da } \\
\text { organização com controles } \\
\text { internos e compliance e } \\
\text { geração de confiança aos } \\
\text { stakeholders bem como } \\
\text { prestação de contas frente } \\
\text { aos objetivos da Cia }\end{array}$ & $\begin{array}{l}\text { Preocupação em } \\
\text { validar os processos } \\
\text { para não expor a } \\
\text { organização }\end{array}$ & $\begin{array}{l}\text { Consciência da sua } \\
\text { responsabilidade e o } \\
\text { impacto para } \\
\text { organização }\end{array}$ & & 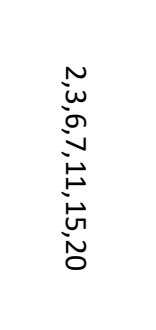 \\
\hline
\end{tabular}

Quadro 2: Espaço de resultado
Fonte: Elaborado pela autora 


\section{6 \\ Considerações finais}

Neste capítulo serão desenvolvidas as principais considerações e contribuições desse estudo, bem como sugestões e recomendações para novas pesquisas. Desta forma, serão retomados o objetivo de pesquisa, o respectivo fomento e os principais conceitos envolvidos, culminando nas principais contribuições do estudo.

A accountability envolve múltiplos significados e conceitos. Alguns conceitos que envolvem responsabilidade, controle, transparência, prestação de contas (PINHO e SACRAMENTO, 2008) outros também incluem a capacidade de resposta às expectativas de stakeholders (KOPPELL, 2005). O fomento deste estudo adveio das reflexões de Campos (1990) sobre uma ausência no Brasil não só do conhecimento da palavra, mas também de seu significado, que perpassou pelas reflexões de Pinho e Sacramento (2008), que informam existir uma grande distância até ser estabelecida uma cultura de accountability no Brasil.

Ademais, o presente estudo utilizou como campo de análise as rotinas organizacionais relacionadas a controles internos. Para compor o estudo, foi necessário definir as rotinas organizacionais e caracterizá-las com base nos estudos desenvolvidos nos últimos anos (NELSON e WINTER, 1982; FELDMAN, 2000; FELDMAN e PENTLAND, 2003; PARMIGIANI e HOWARD-GRENVILLE, 2011). É importante ressaltar que por anos as rotinas foram vistas como "inflexíveis" (WEISS e ILGEN, 1985; BAUM e SINGH, 1994) sendo vistas, mais tarde como "flexíveis e mutáveis" (PENTLAND e RUETER, 1994; FELDMAN, 2000). É válido lembrar que as rotinas relacionadas as normas e conformidade já foram consideradas como instrumento de legitimidade organizacional (FELDMAN e MARCH, 1981). Inicialmente, as rotinas de controles internos podem ser vistas como rotinas de conformidade (CHERMAN e ROCHA-PINTO, 2016). Contudo, é válido ressaltar que vários aspectos distintos puderam ser observados nesta pesquisa. Foi possível observar a interação dos elementos que constituem a estrutura interna da rotina (PENTLAND e FELDMAN, 2005), vislumbrar a recursividade entre os aspectos ostensivos e performativos e a interação do artefato com a rotina, em momentos focado somente na 
conformidade, em outros momentos, interagindo com os atores e a própria rotina, culminando numa melhoria de processos.

A partir de uma abordagem fenomenográfica, o objetivo o presente estudo foi compreender a maneira como os envolvidos percebem a accountability nas rotinas de controles internos. Os profissionais eram os denominados "agentes de controles internos", pessoas indicadas por seus gestores para serem os "guardiões" desses processos em suas respectivas áreas de negócio. Cabia a eles participar das rotinas de controles internos, bem como contribuir e interagir com a área de Controles Internos. Os resultados que emergiram das vivências desses indivíduos resultaram na compreensão de accountability em três principais maneiras: respeitar os artefatos; qualificar as rotinas e proteger a organização. Essas formas de entendimento apresentaram as seguintes dimensões explicativas: deferência à transparência; intensidade da interação dos aspectos; senso de responsabilidade e respeito ao controle.

A evolução das categorias descritivas em um passo mais instrumental "respeitar os artefatos", passando para "qualificar as rotinas" em um nível intermediário, até a percepção de accountability como valor "proteger a organização" caracterizaram a abrangência e evolução da complexidade das categorias descritivas.

Com relação às categorias descritivas manifestadas pelos profissionais envolvidos, "respeitar os artefatos" indica que os envolvidos vivenciam a accountability na execução das rotinas relacionadas ao cumprimento de normas internas ou externas. $O$ artefato é relacionado à conformidade e abre pouco espaço para flexibilidade da rotina fora dos seus limites.

A categoria descritiva "qualificar as rotinas" indica que profissionais envolvidos percebem que a accountability é incorporada nas rotinas de controles internos à medida que as atividades garantam e promovam a melhoria das rotinas, utilizando as falhas identificadas para amadurecer os processos, por exemplo.

Já a categoria "proteger a organização" indica que os profissionais envolvidos entendem a accountability no contexto da rotina de controles internos nas atividades e ações que buscam preservar a organização, seja a sua imagem ou aos objetivos estabelecidos pela mesma, atingindo um caráter de valor. Os relatos expõem um comprometimento com a confiança e uma consciência sobre o impacto que as ações tomadas pelos envolvidos podem causar a organização, tanto sob uma visão interna quanto externa, trazendo a luz o poder de agência do indivíduo envolvido na rotina, dado que ele escolhe proteger a organização. 
Para Koppell (2005) colocar camadas de significados em uma única definição de accountability tornaria o conceito sem sentido além de que a definição desta palavra diz respeito as crenças sobre a relação ideal entre os atores envolvidos. Alguns relatos apontam a transparência como uma dimensão explicativa de accountability, apresentando atividades que envolvam ou busquem uma transparência nos dados, nos erros identificados, um comprometimento com a confiabilidade e segurança passada aos stakeholders e aos objetivos da organização, demonstrando seguirem uma linha a partir doas reflexões de Koppell (2005) e de Pinho e Sacramento (2008).

Outra consideração desta pesquisa foi identificar a intensidade da interação dos aspectos como dimensão que explica a accountability. Para os profissionais, mesmo que acompanhando a graduação da categoria, a recursividade entre os aspectos ostensivos e performativos fomentam melhorias nos processos, um amadurecimento das rotinas que buscam desde evitar uma penalidade à organização, a preocupação em manter processos com qualidade para não expor a organização, uma preocupação reputacional. Essa perspectiva também apresenta o artefato com um papel importante nas melhorias dos processos, tentando fazer um contraponto entre as legislações obrigatórias e qual a melhor forma de atendê-las mantendo um processo "vivo" e atento ao aspecto performativo e ostensivo da rotina. Foi possível visualizar a tentativa dos atores em trabalhar os componentes da estrutura interna da rotina (PENTLAND e FELDMAN, 2005) em busca da qualidade nos processos.

Alguns relatos também apresentaram variações no senso de responsabilidade. Os relatos expõem não apenas uma preocupação ou uma responsabilidade em atender uma determinada norma; ele perpassa pela responsabilidade em realizar e melhorar as rotinas, chegando ao nível de consciência do impacto das ações dos agentes envolvidos na organização, passando de uma visão micro, onde há um interesse somente individual, para uma visão macro, sobre um interesse coletivo, considerando as áreas, o impacto no negócio, a imagem da organização.

Também é válido destacar que os relatos apresentaram o controle com um dos aspectos que explicam as categorias. Apesar de se tratar da percepção de accountability nas rotinas de controles internos e, em princípio, haver uma correlação entre "controle interno" e o "controle" vivenciado pelos profissionais envolvidos, é importante ressaltar que os relatos demonstraram não apenas o controle de uma maneira pura, ou seja, centrado em cumprir regras, procedimentos, mitigar riscos; mas também consideraram a revisão dos 
controles para garantir a realização dos processos. Neste âmbito, podemos considerar que as atividades de controle sob a visão de accountability parecem querer garantir um ambiente de controle $(\mathrm{COSO}, 2013)$ que conheça seus riscos e aperfeiçoe seus controles a fim de garantir a execução e qualidade dos processos.

Este estudo sugere então que, as dimensões explicativas de accountability parecem estar em linha com instituições que estabelecem melhores práticas de mercado relacionadas a uma estrutura de controles internos, a exemplo do coso (2013), que na definição de controles internos engloba aspectos relacionados à conformidade com as legislações, transparência e divulgação de informações confiáveis. Desta forma, é oportuno considerar uma proximidade do conceito de accountability percebido pelos entrevistados ao conceito de controle interno e as respectivas rotinas estabelecidas.

Outra contribuição que o presente estudo destaca é que os achados podem servir de subsídios para as empresas de maneira geral, a fim de considerar as possíveis percepções dos agentes envolvidos nas rotinas de controle internos; como refletem sobre os artefatos, seus processos e as melhores práticas, tão comum ao ambiente empresarial. Além disso, o presente estudo pode contribuir para uma reflexão sobre o desenvolvimento da accountability nas organizações.

Por fim, cabe a este estudo considerar as reflexões de Campos (1990) e Pinto e Sacramento (2008) que apontam um desconhecimento da palavra accountability e um reduzido senso frente ao um conceito que apresenta múltiplos significados. Este estudo apresenta sinais, mesmo que parciais, de que, desde os estudos apresentados pelos autores, há percepções expostas nos relatos que apresentam evoluções na significação de um conceito tão distante na visão de Campos (1990). Embora este estudo não tenha subsídios para relacionar diretamente as questões políticas tão discutidas pelos autores que refletem a accountability sob o olhar das percepções dos cidadãos brasileiros frente a administração pública, é importante considerar que, o IBGC (2015) expõe um conceito de cidadania corporativa envolvendo uma organização responsável, que considera não somente as legislações aplicáveis, mas os stakeholders envolvidos e tem consciência das ações organizacionais e os efeitos que causam a sociedade, apresentando uma semelhança às características consideradas apropriadas por Campos (1990) para a relação entre o cidadão e administração pública. Desta forma, levando em consideração os resultados dessa investigação, pareceu visível a relação dos entrevistados 
com a responsabilidade objetiva e subjetiva de seus atos; uma preocupação com a organização a partir dos interesses da organização como um todo e com transparência tanto com relação aos erros, quanto as informações que corroboraram as performances dessa organização, o que aparenta ser uma versão não tão utópica do que Pinho e Sacramento (2008) consideram de cultura de accountability. Desta forma, ainda cabe considerar que, apesar de não responder a perguntar feita pelos autores quanto à possibilidade de tradução do termo accountability para o português, utilizada como fomento das discussões sobre o tema, este estudo sugere, com base nas evidências da investigação, que há um entendimento do conceito para os profissionais envolvidos nas rotinas de controles internos. Contudo, as próprias variações das categorias descritivas demonstram que ainda há um longo caminho a percorrer a fim de que a accountability seja internalizada em sua totalidade ao âmago desses profissionais.

\section{1 . \\ Sugestões e recomendações para novas pesquisas}

Com base nos resultados encontrados, cabe sugerir para pesquisas futuras investigar a compreensão de accountability em empresas não reguladas, no intuito de apresentar a compreensão do fenômeno em um ambiente em que o regulador não aparece tão fortemente. Surge ainda, a possibilidade de comparar as duas visões, a fim de que a pesquisa talvez exponha se há sinergia ou divergências entre as percepções identificadas.

Também seria oportuno investigar sobre o poder das estruturas de controles internos e o seu papel dentro da organização. Por vezes, nesta pesquisa, os entrevistados confundiram os papéis da área de controles internos e do responsável pelo controle interno na área de negócio. Desta forma, seria interessante avaliar o quanto cada agente da rotina "invade" o espaço ou o papel do outro. Além disso, avaliar quanto o poder da estrutura de controles internos pode impactar ou como ele é percebido pelos envolvidos nas rotinas.

Adicionalmente, a investigação estimulou a curiosidade sobre a aplicação da questão central desse estudo para indivíduos que vivenciem a administração pública, visto que apresentam contextos distintos das rotinas organizacionais, outros agentes envolvidos nas rotinas e aproximar-se um pouco mais às questões levantadas por Campos (1990) e Pinho e Sacramento (2008). 
Por fim, mais especificamente com relação às rotinas organizacionais, sugere-se como agenda a próximos estudos, investigar a evolução das rotinas de controles internos, no sentido de avaliar o quanto ela pode evoluir de algo limitador, como uma rotina focada na conformidade, a algo fluido, que possa demonstrar os aspectos de fluidez de uma rotina organizacional. 


\section{Referências bibliográficas}

AKERLIND, G. L. Variation and commonality in phenomenographic research methods. Higher Education Research \& Development. v. 24, n. 4, November, 2005, p. 321-334.

ATTIE, W. Auditoria: conceitos e aplicações. São Paulo: Atlas, 2011.

BAUM, J. A. C.; SINGH, J. V. Evolutionary Dynamics in Organizations. New York: Oxford University Press, 1994.

BORGERTH, V. M. C. A lei Sarbanes-Oxley: um caminho para a informação transparente. $141 \mathrm{f}$. Dissertação de Mestrado - Faculdades IBMEC, Programa de Pós-Graduação e Pesquisa em Administração e Economia, Rio de Janeiro, 2005.

BOWDEN, J. A. Reflections on the phenomenographic team research process. In: BOWDEN, J. A.; GREEN, P. (Orgs.) Doing developmental phenomenography. Qualitative Research Methods Series, Melbourne: RMIT University Press, p. 11-31, 2005.

CAMPOS, A. M. Accountability: quando poderemos traduzi-la para o Português? Revista de Administração Pública. Rio de Janeiro. Fev./Abr. 1990.

COHEN, M. Reading Dewey: Reflections on the Study of Routine. Organization Studies, v. 28, p. 773-786, 2007.

CHERMAN, A.; ROCHA-PINTO, S. R. Valoração do conhecimento nas organizações e sua incorporação nas práticas e rotinas organizacionais. Revista Brasileira de Gestão de Negócios, v. 18, n. 61, p. 416-435, 2016.

COLLINS - Dicionário Prático Inglês-Português / Português-Inglês. Editora Siciliano. São Paulo. 1991.

CRESWELL, J. W. Projeto de pesquisa métodos qualitativo, quantitativo e misto. In: Projeto de pesquisa métodos qualitativo, quantitativo e misto. Artmed, 2010.

D'ADDERIO, L. Artifacts at the centre of routines: performing the material turn in routines theory. Journal of Institutional Economics, v. 7 Iss 2, p. 197-230, 2011.

. The performativity of routines: Theorising the influence of artefacts and distributed agencies on routines dynamics. Research Policy, v. 37, n. 5, p. 769789, 2008. 
FELDMAN, M. S. Organizational routines as a source of countinuous change. Organization Sciences, v. 11, n. 6, p. 611-629, 2000.

; MARCH, J. G. Information in organizations as signal and symbol. Administrative Science Quarterly, v. 26(2), p. 171-186, 1981.

.; PENTLAND, B. T. Re-theorizing organizational routines as a source of flexibility and change. Administrative Science Quarterly, v. 48(1), p. 94-118, 2003.

FERNANDES, M. A. Introdução à fenomenografia: Potencialidades de aplicação à investigação em enfermagem. Revista Investigação em enfermagem, v. 12, p. 3-10, 2005.

FIGUEIRA, E. C. S. Compreendendo as rotinas organizacionais: percepção de consultores em suas experiências de campo. 97f. Dissertação de Mestrado Departamento de Administração, Pontifícia Universidade Católica do Rio de Janeiro, Rio de Janeiro, 2016.

FRIESL, M.; LARTY, J. Replication of routines in organizations: Existing literature and new perspectives. International Journal of Management Reviews, v. 15 Iss 2, p. 106-122, 2013.

GREEN, P. et al. A rigorous journey into phenomenography: From a naturalistic inquirer standpoint. Doing developmental phenomenography, $p$. 32, 2005.

HANNAN, M. T.; FREEMAN, J. R. Structural inertia and organizational change. American Sociological Review, v. 49, p. 149-164, 1984.

JARDIM, L. S. A compreensão das competências nas rotinas de programação da produção. 98f. Dissertação de Mestrado - Departamento de Administração, Pontifícia Universidade Católica do Rio de Janeiro, Rio de Janeiro, 2017.

KOPPELL, J. G. S. Pathologies of accountability: ICANN and the challenge of "multiple accountabilities disorder". Public Administration Review, v. 65, n. 1, p. 94-108, january/february, 2005.

LATOUR, B. The powers of association. In 1. Law. Power, action and belief: A new sociology of knowledge, 1986.

MACKENZIE, D. An Engine, Not a Camera: How Financial Models Shape Markets. Cambridge, MA. MIT Press, 2006.

MAIA, M. S. et al. Contribuição do sistema de controle interno para a excelência corporativa. Revista Universo Contábil, v. 1, n. 1, p. 54-70, 2005.

MARTON, F. Phenomenography - describing conceptions of the world around us. Instructional science, v. 10, n. 2, p. 177-200, 1981. .; BOOTH, S. A. Learning and awareness. Psychology Press, 1997.

MICHAELIS - Dicionário Prático Inglês-Português / Português-Inglês. Melhoramentos. São Paulo. 1988.

NELSON, R. R.; WINTER, S. G. An evolutionary theory of economic change. Harvard University Press, 1982. 
OXFORD Advanced Learner's Dictionary. Oxford University Press. Oxford. New York. 2005.

PARMIGIANI, A.; HOWARD-GRENVILLE, J. Routines revisited: Exploring the capabilities and practice perspectives. Academy of Management Annals, v. 5, n. 1, p. 413-453, 2011.

PENTLAND, B. T.; FELDMAN, M. S. Designing routines: On the folly of designing artifacts, while hoping for patterns of action. Information and Organization, v. 18, n. 4, p. 235-250, 2008.

.; FELDMAN, M. S. Issues in empirical field studies of organizational

routines1. Handbook of organizational routines, p. 281, 2008a.

.; FELDMAN, M. S. Organizational routines as a unit of analysis.

Industrial and corporate change, v. 14, n. 5, p. 793-815, 2005.

; REUTER, H. H. Organizational routines as grammars of action.

Administrative Science Quarterly, v. 39, p. 484-510, 1994.

PINHO, J. A. G.; SACRAMENTO, A. R. S. Accountability: já podemos traduzi-la para o português?. Revista de Administração Pública, v. 43, n. 6, p. 13431368, 2009.

SANCHES, M. V. Sistemas de Controles Internos e de Fiscalização em Demonstrações Contábeis: Uma Análise Crítica de Normas Específicas. Dissertação (Mestrado em Ciências Contábeis). Pós-Graduação em Faculdade de Economia, Administração e Contabilidade. Universidade de São Paulo, São Paulo, 2007.

SANDBERG, J. Understanding human competence at work: an interpretative approach. Academy of management journal, v. 43, n. 1, p. 9-25, 2000.

TROSA, S. Gestão pública por resultados: Quando o Estado se compromete. Brasília: ENAP, 2000.

VERGARA, S. C. et al. Paradigma interpretacionista: a busca da superação do objetivismo funcionalista nos anos 1980 e 1990. Revista de Administração de Empresas, v. 45, n. 4, p. 66-72, 2005.

WEISS, H. M.; ILGEN, D. R. Routinized behavior in organizations. Journal of Behavioral Economics, n. 14, p. 57-67, 1985. 


\section{Sites visitados}

Association of Certified Fraud Examiners. Report to The Nations on Occupational Fraud And Abuse. Austin, 2016. Disponível em: <http://www.acfe.com/rttn2016.aspx>. Acesso em: 12 de fevereiro. 2018.

Banco Central do Brasil. Resolução no 2554. Brasília, 1998. Disponível em: < http://www.bcb.gov.br/pre/normativos/res/1998/pdf/res_2554_v2_P.pdf $>$. Acesso em: 12 de fevereiro. 2018.

Banco Central do Brasil. Circular no 3467. Brasília, 1998. Disponível em: < https://www.bcb.gov.br/pre/normativos/busca/downloadNormativo.asp?arquivo=/ Lists/Normativos/Attachments/47518/Circ_3467_v1_O.pdf>. Acesso em: 12 de fevereiro. 2018.

CAMBRIDGE Dictionary. Disponível em: $<$ https://dictionary.cambridge.org/pt/dicionario/ingles/accountability\#translations $>$. Acesso em: 15/02/2018.

Committee of Sponsoring Organizations of the Treadway Commission. Internal Control - Integrated Framework, 2013. Disponível em: $<$ https://www.coso.org/Documents/990025P-Executive-Summary-finalmay20.pdf. $>$ Acesso em: 14/01/2018.

GASTIM, I. C. Combate a Corrupção "engatinha" no setor empresarial. Estadão - Portal do Estado de São Paulo, São Paulo, 9 dez. 2014. Disponível em: <http://economia.estadao.com.br/noticias/governanca,combate-a-corrupcaoengatinha-no-setor-empresarial,1604070 >. Acesso em: 12 de fevereiro. 2018.

Instituto Brasileiro de Governança Corporativa. Código das melhores práticas de governança corporativa. 5.ed, 2015. Disponível em:

$<$ http://www.ibgc.org.br/index.php/publicacoescadernos-de-governanca>. Acesso em: 14/01/2018

MICHAELIS - Moderno Dicionário de Ingês. Disponível em:

$<$ http://michaelis.uol.com.br/moderno-ingles/busca/ingles-portugues-

moderno/accountable/>

Origem da Palavra - Site de Etimologia. Disponível em:

<origemdapalavra.com.br/>. Acesso em: 15/02/2018.

PORTAL da Auditoria - Disponível em:

$<$ https://portaldeauditoria.com.br/panorama-das-diretrizes-coso-e-cobit/>. Acesso em: 15/02/2018.

Superintendência de Seguros de Seguros Privados. Circular SUSEP no 249. Rio de Janeiro, 2004.2 Disponível em: <http://www2.susep.gov.br/bibliotecaweb/docOriginal.aspx?tipo=1\&codigo=147> . Acesso em: 12 de fevereiro. 2018. 


\section{Apêndice I \\ Roteiro Semi-estruturado}

Apresentação

Olá! Você me autoriza a gravar nossa conversa? Esse procedimento facilitará a retomada do conteúdo posteriormente. Estou entrevistando funcionários envolvidos com atividades de controles internos para minha investigação a fim de compreender a accountability (responsabilização) nas rotinas (atividades) de controles internos. Para tanto, a identidade do entrevistado não será revelada e o seu relato utilizado para fins acadêmicos. Fique a vontade para abordar o que considerar relevante acerca do que for questionado.

\section{Perguntas Introdutórias:}

1) Inicialmente, para contextualizar a nossa conversa, você poderia me falar qual a sua formação e tempo de experiência profissional?

2) Você poderia me falar um pouco sobre sua trajetória profissional até o momento atual. Quais as principais atividades desenvolvidas?

3) Você poderia me dizer o que é controle interno para você?

\section{Perguntas Intermediárias:}

\section{Ler uma breve definição de accountability.}

5) Como você percebe que a accountability é incorporado nas práticas/rotinas de controle interno?

6) Você poderia me dar um exemplo de alguma situação, dentro das experiências vividas até o momento em controle interno, em que você considera que a accountability aconteceu? Onde, quando, de que forma? $O$ que favoreceu? O que dificultou?

Obs: Você pode dar um exemplo. (Pedir sempre)

\section{Perguntas de acompanhamento:}

a. Por que você considera essa situação é uma evidência de favorecimento? Ou de dificuldade?

b. Se foi pessoal, o que isso significou para você? 


\section{Perguntas Finais:}

7) Agora, eu gostaria de voltar um pouco e, a partir do que conversamos e dos exemplos que você me deu. Vou te pedir para você pensar e me dizer, de uma forma resumida, o que a accountability no contexto das rotinas de controle interno significa pra você. (perguntas auxiliares: o que você entende por accountability no contexto de controle interno OU como você definiria accountability no contexto de controle interno).

8) Você gostaria de acrescentar algo ao que você disse anteriormente ou dizer alguma coisa sobre o assunto que não foi abordado na nossa conversa?

\section{Perguntas Acessórias:}

a. Você poderia me dar um exemplo?

b. Você poderia me explicar (isso) melhor?

c. Como você faz/fez (isso)?

d. Por que (isso) ocorreu?

e. Como você superou (isso)?

f. Como (isso) te ajudou?

g. Para quem?

h. Por que?

\section{Encerramento:}

Agradecimentos 


\section{Apêndice II \\ Lista de termos específicos}

\begin{tabular}{|l|l|l|}
\hline 1 & PEP & Pessoa Politicamente Exposta \\
\hline 2 & $\begin{array}{l}\text { Nota Técnica } \\
\text { Atuarial }\end{array}$ & $\begin{array}{l}\text { Documento que contém os cálculos atuariais das } \\
\text { regras de negócio }\end{array}$ \\
\hline 3 & Circular 445 & $\begin{array}{l}\text { Circular que dispõe procedimentos de prevenção e } \\
\text { combate à lavagem de dinheiro }\end{array}$ \\
\hline 4 & RCF & Cobertura de seguros para terceiros \\
\hline 5 & Matriz de Riscos & $\begin{array}{l}\text { Documento que contém os riscos e controles de um } \\
\text { determinado processo }\end{array}$ \\
\hline
\end{tabular}

